\title{
社会基盤整備・運用事業の経済リスク管理問題に対する \\ ファイナンスエ学的アプローチ*1
}

Financial Engineering Approachs to Dynamic Pricing and Management of Infrastructure Projects Risk*1

赤松 隆*2, 長江 剛志*3

By Takashi AKAMATSU², Takeshi NAGAE*3

\section{1 はじめに}

社会基盤施設の整備・運用プロジェクト (以下，IP と書く)は，一般に，社会・経済的側面と財務的側面の 2 つの観点から評価される. 前者は, 従来から土木計 画学分野の重要課題と認識され，その代表的方法であ る経済的便益費用分析に関する多くの研究が, 理論・ 実証の両面から，蓄積されてきた，一方，後者は，通 常, IP に限らない一般的な実物投資プロジェクトでも 実施される．そのためか，土木計画分野では，財務的 な分析・評価法に関しては, 研究の必要性すら顧みら れてこなかったきらいがある.

しかし，近年，IPにおいても，財務的観点からの分 析と評価の重要性が高まりつつある。その背景は, 先 進諸国で，IP 一の民間・市場からの資金・ノウハウの 導入，及びリスク管理の必要性が要請され始めたこと にあろう。実際，わが国でも，IP の民営化 (e.g., 道路 公団), PFI や証券化スキーム (e.g., 熱海観光道路)によ る事業実施が始まりつつある。また，リスク管理につ いても，'90 年代のバブル経済破綻や経済のグローバ ル化進展といった事業環境の変化を経験し, その必要 性の認識が高まっている．このような潮流は今後も続 くと考えられ，そのための方法論を体系的に構築して ゆくことは, 土木計画学においても重要な課題である.

財務 (ファイナンス) 論的にみれば，IPは，その事業 から発生するキャッシュ・フロー流列を受け取る権利 に過ぎない.この一見単純な権利の財務的評価は, 実 は, みかけほど易しいものではない.もちろん, 仮に 一定の経済条件下での確定的なキャシュ・フローが保 証されるなら，その評価・分析は極めて単純である. しかし，現実には，事業をとりまく経済環境 (e.g.,.金 利・為替・景気) は一定ではなく, 長期にわたって発生

\footnotetext{
*1 キーワーズ : ファイナンス工学, 不完備市場, 一般化相補性 アプローチ, オプション・グラフ

*2 工博, 東北大学大学院情報科学研究科 (广980-8579 仙台市青 葉区荒巻字青葉 06)

*3 博士 (情報科学), 神戸大学大学院自然科学研究科 ( $\bar{T} 657-8501$ 神戸市灘区六甲台町 1-1)
}

するキャシュ・フローも確実な予測の困難な確率過程 である。これらの不確実性から発生する動的な “経済 リスク”を適切に分析・評価するためには, 首尾一貫 した理論的枠組みが必要である。また, 社会基盤施設 の安定的な運用のためには, 経済環境の変化に応じた フィードバック的意思決定によって, 経済リスクを制 御 (“リスク・ヘッジ”)する方法も求められるであろう.

このような経済リスクを考慮した IP の財務的分析・ 評価の方法論は，その必要性にも関わらず，未だ確立・ 普及しているとは言い難い. 実際，IPにおける財務的 評価は, 古典的な会計学の枠組での分析にとどまり, リスクの考慮は，期待純現在価值法や修正割引率法と いった素朴な手法で対処しているのが現状である。こ れらは，アド・ホックな便法に過ぎず，事業が抱える 動学的なリスクをシステマティックに評価しうる論理 構造を備えていない，さらに，従来手法は，市場で観 測される資産・証券価格に含まれている“リスクの市 場価格”に関する情報を十分に活用していない，その ため，主観的・恣意的な評価に陥りやすいのみならず， 例えば，事業契約に含まれる“オプション価值” の計 量, あるいは金利変動リスクの計量といった動学的な 問題を市場情報と矛盾無く扱うことは難しい.

一方, ファイナンス分野では, 証券 (金融・資本)市場 で取引される金融資産を対象として，その合理的評価 および投資・運用に伴う動学的リスク制御のための理 論が発展してきた. その代表的理論がオプション (条 件付請求権) 洒格理論である. また, この理論を中心と する金融リスク管理法の研究は, 数学, 情報科学, 計算 工学等の諸分野と融合し, ファイナンス工学 (Financial Engineering) と呼ばれる一大分野を形成している。そ して，そこで開発されたリスク計量化・制御技術の普 及は，世界中の金融・資本市場構造やファイナンス実 務を劇的に変化させるに至っている.

金融資産であれ，IP(あるいは一般の実物投資事業) であれ, ファイナンス論的には, 確率的キャッシュ・フ ローを受取る権利契約である. 従って, IP のリスク評 価・管理法として, ファイナンス工学的アプローチを 
検討してみることは，極めて自然である，ただし，従 来のファイナンス工学は, (主に) 証券市場で取引され る資産を対象とした方法論であり, IP のような複雑・ 大規模な実物投資プロジェクトに，そのままナイーブ に適用できるものではない. 実際, 2 章で説明するよ うに, IP の財務的評価のためには, 従来のファイナン ス理論をいくつかの方向に拡張／一般化した理論が必 要である. 本稿では, そのために筆者らが行なった研 究を簡潔に紹介し, 今後の研究課題・展望を議論する.

本稿の構成は以下の通りである。まず, 第 2 章では, 従来の (金融・リアル) オプション理論を IP 評価へ応 用することの可能性と限界を議論する. 次に, 第 3 章 および第 4 章では, これら理論の融合と拡張を企図し た筆者らの研究を紹介し, 今後の研究課題を述べる. より具体的には, 第 3 章では, 実物投資プロジェクト の “不完備市場リスク”を考慮した上で，その財務的価 格を動学的に評価する方法を示す. 第 4 章では, 実物 投資プロジェクトの特徴である “意思決定の柔軟性と 連鎖性”を一般的に扱うことのできる“オプション・グ ラフ理論”を紹介する. 最後に, 第 5 章は, まとめで ある。

\section{2 従来研究と本研究の考え方}

\section{（1）従来のオプション理論の特徵と限界}

オプション価格理論，及び，それを含む金融資産価 格理論全般の体系的内容は, 膨大な数の出版物 (例え ば，付録に記した様々なレベル・観点から書かれた教 科書・専門書)において, 既に詳細に解説されている. 従って, 以下では, ファイナンス理論における初等的 用語・概念に関する予備知識は与件とした上で, IP の 評価に関連する点のみに限定したオプション理論の特 徵と限界を簡潔に議論する.

Black and Sholes ${ }^{1)}$, Merton $^{2)}$ に始まる金融オプショ ン理論は, 市場資産取引における無裁定条件のみに依 拠して, オプション価格を決定する.この理論では, 通 常の均衡理論とは異なり, 経済主体の選好条件 (e.g., 効 用関数) や市場の需給均衡条件は不要である. そのよ うなことが可能となる理由は, このアプローチが,オプ ション価格を(観測されている) 原資産価格の関数とし て表現する,すなわち, “相対価格の理論”となってい るからである. 経済学的な意味の理解しやすい別の表 現をすれば, このアプローチは, Arrow-Debreuの(不 確実性下に拡張された) 一般均衡理論における条件付 請求権 (“Arrow-Debreu 基本証券”) の価格を, 観測され る資産価格から “逆推定”する具体的な手続きを与えて
いるのである.この事情は, 古典的な Black- Sholes 理 論であれ, より一般化・抽象化されたマルチンゲール・ アプローチ (e.g., Harrison-Kreps ${ }^{3)}$, Harrison-Pliska ${ }^{4}$, Heath-Jarrow-Morton $\left.{ }^{5,6)}\right)$ であれ，同じである.

このアプローチによってオプション価格を一意的に 決定できるのは, 観測資産価格から Arrow-Debreu 基 本証券価格を一意に推定できる場合である。これは, 離散的な状態空間なら, 将来起こりうる状態の数が, 線形独立なペイ・オフ・ベクトルを持つ資産の個数と 同じか小さい場合，すなわち，“完備市場”の条件が満 たされる場合に限られる. 具体的な資産取引(リスク・ ヘッジ)操作と関係付けて言えば，当該オプションの取 引がもたらすリスクが, 資産取引によって完全にヘッ ジできる (i.e. 市場で取引される証券・資産を組み合わ せた動的ポートフォリオ運用によって，キャッシュ・ フローを完全に replicate できる) 場合を意味している.

このことは, 標準的なオプション理論の適用限界を 意味している，すなわち，当該オプションがもたらす リスクを資産取引によって完全にヘッジすることが不 可能な “不完備市場”では, この理論のみでオプション 価格を一意に決定することはできない. このオプショ ン理論の限界が IP のリスク評価に与える問題点につ いては, 以下の (2)で, より具体的に説明する.

なお, 相対価格アプローチと対になる “絶対価格アプ ローチ”は，市場の需給均衡概念に基づいて資産・証券 価格を説明する需給均衡理論 (e.g., CAPM: Capital Asset Pricing $\mathrm{Model}^{7,8,9)}$ や, その動学版である ICAPM: Intertemporal CAPM $^{10)}$, CCAPM: Consumption-based $\left.C A P M^{11)}\right)$ である。そこでは，市場取引されている全 資産の価格は, 経済主体の基本条件 (e.g., 効用関数, 生産関数, 初期財産等) のみで表現されることになる. この均衡アプローチは, 不完備市場における資産価格 や経済厚生状態の本質的特性を解明するためには必須 であり, また, 純粋理論的な枠組みとしては優れてい る.しかし，現在までに確立している代表的消費者に よる記述を用いた均衡理論は, その実証的妥当性に関 しては, "Equity Premium Puzzle12)” や “Risk-free Rate Puzzle ${ }^{13) ”}$ ”代表される多くの否定的結果が指摘され ている. 従って, 均衡理論アプローチは, 現時点では, IP のリスク計量化といった問題に適用できる段階には ないと思われる.

さて, 上記の金融オプション理論や動的ポートフォ リオ理論に見られるように, ファイナンス分野では, (対象は金融資本市場に限定されているものの) 確率 過程としての状態表現や確率的制御理論をベースと 
する動学的なリスク管理手法が定着している.このよ うなアプローチを実物投資問題に適用する試みの一 つとして, 従来から知られているのが, リアル・オプ ション理論である.この初期の研究 (e.g., Brennan and Schwartz ${ }^{14)}$, McDonald and Siegel $\left.{ }^{15,16)}\right)$ は，不可逆な 実物投資問題において，投資を延期するオプションの 価值と投資タイミングの決定法を与えている(これは, 概念的には，金融オプション理論におけるアメリカン・ オプション問題, あるいは, 費用便益分析における準 オプション価值 ${ }^{17,18)}$ 問題とほぼ同様の問題である). その後, 様々な研究と応用が進展し(例えば, Dixit and Pindyck ${ }^{19)}$ 参照), 最近では, 土木計画分野においても, IP を念頭に置いた理論の拡張が進められている.

しかし, 従来のリアル・オプション研究の大半は, プロジェクト・リスクと金融市場の完備性・不完備性 に関しては，乱暴／無頓着な扱いをしている.すなわ ち, プロジェクトのキャッシュ・フロー変動が, (1)完 備市場リスクか, (2)完全に不完備リスク; という両極 端な仮定の場合しか扱っていない. 前者は, 金融市場 で完全にリスク・ヘッジできる，つまり，実物投資プ ロジェクトと金融オプションとの間に(理論的には) 何 ら相違がない場合である，後者は，プロジェクトのリ スクは，金融資産の取引では全くヘッジできない場合 である. いずれも，IP の定量的リスク分析を考える上 では, 結局, 金融オプション理論以上に有用な情報を 与えているとは言い難い.

これに加え, 従来のリアル・オプション理論をIP の 定量的リスク分析に適用しようとすると, モデル化さ れている意思決定構造の限界に遭遇するだろう。従来 研究の大半は, 概念的分析 (モデルの定性的性質や経済 学的解釈の導出) を指向しているため, 非常に限定的 な仮定下での “toy model”を扱ったものが大半である. すなわち, 解析解が得られるような極端に簡略化され た問題のみを対象としているため，その理論は，多く の IP で重要となる連鎖的な意思決定構造を明示的に 考慮できない. この問題点については，以下の (3) で, より詳しく説明する.

\section{(2) プロジェクトの経済リスクと不完備市場}

IP におけるキャッシュ・フローの確率的変動は, 金 融・資本市場で取引されている資産価格・経済状態変 数と何らかの相関を持つ場合が多い, しかし, その確 率変動は, 市場でヘッジできない経済リスク要因にも 依存するのが普通である，例えば，IPで受け取ること のできるキャッシュ・フロー $P(t)$, および市場取引さ れているある資産の価格 $S(t)$ が，各々，

$$
\begin{aligned}
& \mathrm{d} P(t) / P(t)=\mu_{P} \mathrm{~d} t+\sigma_{1,1} \mathrm{~d} W_{1}(t)+\sigma_{1,2} \mathrm{~d} W_{2}(t), \\
& \mathrm{d} S(t) / S(t)=\mu_{S} \mathrm{~d} t+\sigma_{2,1} \mathrm{~d} W_{1}(t),
\end{aligned}
$$

ここで, $W_{1}, W_{2}$ は独立な標準 Wiener 過程, と表現で きたとしよう。このとき，2つの確率過程は共分散が $\sigma_{1,1} \sigma_{2,1}$ の相関をもつ. しかし, これらは, 完全相関 しているわけではない; リスク要因 $W_{1}$ に起因する $P$ の確率変動は, 市場資産 $S$ との適切な組合わせにより 完全にヘッジできるが, リスク要因 $W_{2}$ に起因する確 率変動まではへッジできない. すなわち, IP のキャッ シュ・フローは, 市場ではヘッジできない“不完備市 場リスク”に曝されている. 従って, 完備市場を仮定 した金融オプション理論を, IP の評価に，そのまま適 用することは妥当ではない. 実際, そのようなナイー ブな理論の適用 (誤用) は, 市場取引されないリスク要 因 $W_{2}$ を完全に無視するというリスクをとっているこ とになる.

このような問題意識から, 赤松・長江 ${ }^{20)}$ は, IP 等の 実物投資事業の価格評価を, “不完備市場”におけるオ プション評価問題ととらえた新しいアプローチを提案 した，すなわち，事業は，(1)確率的な “状態変数” の関 数として定義されたペイ・オフを持つオプション (条 件付請求権) であり, (2) その状態変数は, 市場で取引 可能な資産・証券の売買によってヘッジ可能なリスク 要因とヘッジ不可能なリスク要因から構成されると考 える. そして, オプション評価問題を, 市場で観測さ れる資産・証券価格情報と無裁定条件から上記リスク 要因の価格 (ひいては, オプション価格) を推定する“ 逆問題”ととらえる. その上で, この逆問題に, 不完 備市場リスクの価格を推定するための最小限の仮定を 追加したモデルを定式化し, そのメカニズムおよび特 性を明らかにした。 さらに, 長江・赤松 ${ }^{21)}$ では, この 枠組みを, 権利行使時点も選択可能なオプションへと 拡張している (筆者らの研究と関連する従来研究のよ りテクニカルなレビューについては, 赤松・長江 ${ }^{20)} を$ 参照). 第 3 章では, この具体的な内容を紹介し, さら に, これに関連した今後の研究課題を議論する.

\section{（3）プロジェクト意思決定の不可逆性・柔軟性と連}

\section{鎖性}

IP は, 一般に, 様々な経済活動状態 (以下, “アクティ ビティ”)から構成される，そして，事業主体は，(原理 的には) 不確実に変動する状況に応じて, これらのア クティビティを切り替えることができる，例えば，不 動産施設運用事業において, 施設の遊休化および運用 再開が可能な場合を考えよう。この場合, 施設を運用 している状態, および施設を遊休させている状態のそ 
れぞれがアクティビティに相当し，事業主体は，時々 刻々変動する施設需要に応じて, 需要が低迷した時に は運用から遊休へ, その後, 需要が回復した時には遊 休から運用へとアクティビティを切り替えられる.

このような意思決定は, “アクティビティを切り替え られる権利 (オプション)”の行使と見なすことができ る. そして, 当該プロジェクトは, こうしたオプショ ンの集合から構成される“複合オプション”と捉える ことができる.一般に, これらのオプションの行使は, 複雑な相互依存関係をもつ. 寸なわち, あるオプショ ンの行使によって, 新たなオプションの獲得, あるい は既得オプションの喪失が起こる. そのため, 個々の オプションの価值を独立に評価することは出来ない. このように, IP の財務的評価や意思決定を適切に実施 するには, 権利行使の連鎖的構造を明示的に導入した 複合リアル・オプション問題の分析手法が必要である.

複合オプション評価法の必要性は, 従来, リアル オプション理論，土木計画分野等においても指摘され ており, いくつかの先行研究がある.しかし, それら は, 個別的・部分的な拡張であり, 任意の連鎖的意思 決定構造を扱える一般的な枠組みまでは示されていな い. また, より実際的な条件 (e.g., プロジェクト環境・ 制約の非定常性, 一般的なキャッシュ・フロー過程等) を導入したうえでリスクを計量化できる一般的計算法 も開発されていない(従来研究に関するよりテクニカ ル・詳細なレビューについては, 長江・赤松 ${ }^{22)}$ を参 照). すなわち, 従来の理論は, 複雑な連鎖的意思決定 構造を持つ実際の社会基盤施設の投資・運用問題を対 象とした計量分析に耐えるとは言い難い.

このような従来理論の問題点を受け, 赤松・長江 23), 長江・赤松 22) は, 任意の連鎖的な権利行使構造 をもつ複合リアル・オプション問題をシステマティッ クに記述・分析し，効率的計算法を見通しよく開発す るための枠組を提案した. 具体的には, 第 1 に, 連鎖 的意思決定構造をもつプロジェクトを, それを構成す るサブ・オプションからなる有向グラフ (以下, “オプ ション・グラフ”) として表現する枠組を提案し, 複合 リアル・オプション問題を定式化した. 第 2 に, この 問題が, 時間およびグラフ構造の各々に関して分解で きることを明らかにした．これにより, 非常に複雑で 大規模な問題を, より小規模なサブ問題を逐次的に解 く問題に帰着させられる. 第 3 に, そのサブ問題が, 一般化相補性問題 (GCP: Generalized Complementarity Problem) に帰着することを明らかにし, 効率的な数值 解法を開発した. 第 4 章では, この具体的な内容を紹
介し,さらに, これに関連した今後の研究課題を議論 する.

\section{3 経済リスクを考慮したプロジェク 卜の財務的価格の動的評価}

本章では, 赤松・長江 ${ }^{20)}$ および長江・赤松 ${ }^{21)}$ で提 案した，IP を不完備市場における資産と見なしてその 取引価格を定量的に評価するための方法を解説する. 本章は以下のように構成される.まず, (1)〜 (3) にお いて, 2 時点-離散状態の枠組を用いて, 筆者らの研究 の基本的考え方を簡単に解説する.ここでの分析は, 連続時間-連続状態の枠組へ一般化した上で，オプショ ンの買手がペイ・オフを得る (権利を行使する) タイミ ングを選択できるモデルへと拡張できる．その詳細お よび数值計算方法については, 筆者らの研究 20,21$)$ を 参照されたい. 続いて，(4)では, こうした一般的枠 組の下での数值計算例を用いて, 筆者らの手法と, 従 来の (“完備”あるいは“完全に不完備”な市場を想定し た) 手法との価格評価結果の違いを示す. 最後に, (5), (6) では, 本手法とよく似た数理構造を持つモデルとし て“あいまい性” 回避性向および robust 期待効用モデ ルに着目した研究を紹介し, 本研究との位置付けを明 らかにした上で, 関連する研究課題を述べる.

\section{(1) 2 時点-離散状態モデル}

期首 $(t=0)$ と期末 $(t=T)$ の 2 時点を考える. 期末 で生起する事象の集合を $K \equiv\{1, \cdots, \mathrm{K}\}$ で表現し, 各 事象の生起確率を $\mathcal{P} \equiv\{\mathcal{P}(1), \cdots, \mathcal{P}(\mathrm{K})\}$ とする.

資産市場において, 1 種類の安全資産 (e.g., 債券) と $\mathrm{N}$ 種類の危険資産 (e.g., 証券) が取引されているとす る. 安全資産の期首価格を 1 , 期末価格を $R(>1)$ と する. 危険資産のインデクス集合を $N \equiv\{1, \cdots, \mathrm{N}\}$ と し, $n$ 番目危険資産の期首価格を $s_{n}$, 期末で事象 $k$ が 生起したときの価格を $\hat{S}_{n}(k)$ で, それぞれ表わす. 危 険資産の期末価格を安全資産価格で正規化したものを $S_{n}(k) \equiv \hat{S}_{n}(k) / R$ とする. 以下では，これらを

$\boldsymbol{s} \equiv\left[\begin{array}{c}s_{1} \\ \vdots \\ s_{\mathrm{N}}\end{array}\right], \boldsymbol{S} \equiv\left[\begin{array}{lll}\boldsymbol{S}(1) & \cdots & \boldsymbol{S}(\mathrm{K})\end{array}\right] \equiv\left[\begin{array}{ccc}S_{1}(1) & \cdots & S_{1}(\mathrm{~K}) \\ \vdots & \ddots & \vdots \\ S_{\mathrm{N}}(1) & \cdots & S_{\mathrm{N}}(\mathrm{K})\end{array}\right]$ とベクトル表記する.

期末において (割引き後の) 収益 $\{F(1), \cdots, F(\mathrm{~K})\}$ を 発生させる事業 (i.e., 期末収益 $\{F(k)\}$ に対する請求権) を想定し, その事業の期首での市場取引価格 (事業価 格)を求める問題を考えよう.

まず，市場に裁定機会は存在しない，すなわち，“元 手 0 で正の期待利潤が得られるような投資戦略は存在 
しない”とする。この条件は無裁定条件と呼ばれ，以 下の式を満たす $Q \equiv\{Q(1), \cdots, Q(\mathrm{~K})\}, Q(k)>0, \forall k$ が 存在することと等価であることが知られている ${ }^{3)}$.

$$
\mathbb{E}^{Q}[S] \equiv \sum_{k \in K} Q(k) S(k)=s
$$

ここで，QはP $\boldsymbol{Q}$ に対する等価マルチンゲール測度 (EMM: Equivalent Martingale Measure) と呼ばれ, $\mathbb{E}^{Q}[\cdot]$ は確率測度 $Q$ の下での期待値演算を表す。無裁 定条件下では，任意の資産の期首価格は，EMMの 下での期末価格の期待值に等しい。これより，無裁 定条件を満足するような対象事業の期首価格 (以下, 事業価格) は, $Q$ の下での事業収益 $\{F(k)\}$ の期待值 $C=\mathbb{E}^{Q}[F]$ として求められる. 従って, 事業価格を求 める問題は, 式 (3) からQ を推定する逆問題に帰着 する。

本章が対象とする不完備市場とは, 当該事業から 発生するキャッシュ・フローを, 市場資産の取引で replicate できないことを意味している. すなわち，市 場が不完備であるとは, 数学的には, 独立な市場資産 の数 $\operatorname{rank}(\boldsymbol{S})$ が，期末に起こり得る状態の数 $\mathrm{K} よ り も$ 少ない場合として表現される。このため, 不完備市場 においては，無裁定条件 (3) のみから EMMQ(ひいて は事業価格) を一意に決めることは不可能である。そ こで，事業契約の売手と買手の間の合理的行動一買手 は無裁定条件を満足する中で，なるべく安く買おうと し，売手は極力高く売ろうとする一を導入することで, 事業価格の上限および下限を求めることを考える。こ れらは，それぞれ，以下のように定式化される.

$$
\begin{array}{lll}
{\left[\mathrm{P}_{\mathrm{B}}-0\right]} & C_{\mathrm{B}} \equiv \min _{Q} . \mathbb{E}^{Q}[F], & \text { s.t. (3). } \\
{\left[\mathrm{P}_{\mathrm{S}}-0\right]} & C_{\mathrm{S}} \equiv \max _{Q} . \mathbb{E}^{Q}[F], & \text { s.t. (3). }
\end{array}
$$

ここで，事業価格の下限 $C_{\mathrm{B}}$ および $C_{\mathrm{S}}$ を，それぞれ， 買手価格および売手価格と呼ぶ.

\section{（2）主問題: $K L$ 情報量制約付き EMM 推定問題}

一般に, 無裁定条件のみの下での問題 $\left[\mathrm{P}_{\mathrm{B}}\right],\left[\mathrm{P}_{\mathrm{S}}\right]$ は, 買手価格 $C_{\mathrm{B}}$ あるいは売手価格 $C_{\mathrm{S}}$ が発散し得るという 問題がある。これは，その最適性条件が特異 (singular) な線形逆問題となり得るからである. 本節では，この 価格の発散問題を回避するために筆者らが提案した 手法 ${ }^{20,21)}$ の概念的モデルを解説する. 具体的には, まず，問題 $\left[\mathrm{P}_{\mathrm{B}}-0\right],\left[\mathrm{P}_{\mathrm{S}}-0\right]$ に，客観的確率測度 $\mathcal{P}$ から $\mathrm{EMM} Q \sim$ へ $\mathrm{KL}($ Kullback-Leibler $)$ 情報量に対する下 限制約を追加した問題を定式化する. 次に，こうして
定式化された問題の最適性条件を導出し，それを利用 した事業価格の計算方法を示す。

筆者らの研究では，無裁定条件と KL 情報量制約下 での EMM 推定問題をより見通し良く扱うため, 確 率的割引ファクター (SDF: Stochastic Discount Factor) アプローチを採用している。このアプローチは，資 産評価モデルの実証的検証の枠組として, Hansen and Jagannathan ${ }^{24,25)}$ によって提案されたものである.こ こで, SDF とは, Arrow-Debreu 状態価格に対応する 確率変数であり, 前節の枠組においては以下のように 定義される.

$$
\Lambda(k) \equiv Q(k) / \mathcal{P}(k), \quad \forall k \in K .
$$

この SDF を用いれば，当該事業の事業収益の，EMM $Q$ 下での期待值 (i.e. 事業価格) は, 以下の式 :

$$
\mathbb{E}^{Q}[F] \equiv \mathbb{E}^{\mathcal{P}}[\Lambda F]=\sum_{k \in K} \mathcal{P}(k) \Lambda(k) F(k)
$$

で表される.ここで, $\mathbb{E}^{\mathcal{P}}[X] \equiv \sum_{k \in K} \mathcal{P}(k) X(k)$ は客観 的確率測度 $\mathcal{P}$ の下での期待值演算を表す. また, 確率 測度 $\mathcal{P}$ から $Q$ への KL 情報量は，この SDF を用いた 以下の式で定義される.

$$
\mathcal{H}(Q, \mathcal{P}) \equiv-\sum_{k \in K} Q(k) \ln \frac{Q(k)}{\mathcal{P}(k)}=-\mathbb{E}^{\mathcal{P}}[\Lambda \ln \Lambda] .
$$

筆者らのアプローチでは，無裁定原理のみに基づく 事業価格最小化問題 $\left[\mathrm{P}_{\mathrm{B}}-0\right]$ に対して, KL 情報量の下 限を追加的に設ける. この問題は, $\operatorname{SDF}\{\Lambda(k)\}$ を未知 変数とする以下の問題として定式化できる.

$$
\min _{\Lambda_{\mathrm{B}}} \mathbb{E}^{\mathcal{P}}\left[\Lambda_{\mathrm{B}} F\right], \quad \text { s.t.(3), and }-\mathbb{E}^{\mathcal{P}}\left[\Lambda_{\mathrm{B}} \ln \Lambda_{\mathrm{B}}\right] \geq \hat{H} \text {. }
$$

この問題は, 問題 $\left[\mathrm{P}_{\mathrm{B}}-0\right]$ を $\mathrm{KL}$ 情報量によって正則化 した以下の問題 :

$$
\left[\mathrm{P}_{\mathrm{B}}\right] \min _{\Lambda_{\mathrm{B}}} \mathbb{E}^{\mathcal{P}}\left[\Lambda_{\mathrm{B}} F+\frac{1}{\gamma} \Lambda_{\mathrm{B}} \ln \Lambda_{\mathrm{B}}\right], \quad \text { s.t.(3). }
$$

と 1 対 1 対応関係にある. すなわち, 問題 $\left[\mathrm{P}_{\mathrm{B}}\right]$ のパ ラメタ $1 / \gamma$ が，KL 情報量の下限制約 $\hat{H}$ に対応した

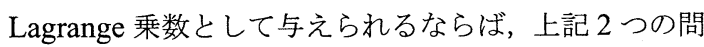
題は等価である(この関係は，後述するように，KL 情 報量の下限 $\hat{H}$ の意味を議論する上で鍵となる).

問題 $\left[\mathrm{P}_{\mathrm{B}}\right]$ の最適性条件より, 買手にとっての最適 $\operatorname{SDF}\left\{\Lambda_{\mathrm{B}}^{*}(k)\right\}$ が従う以下の Logit 式を導出できる.

$$
\Lambda_{\mathrm{B}}^{*}(k)=\frac{\exp \left[-\gamma\left\{F(k)-\boldsymbol{\theta}_{\mathrm{B}}{ }^{\prime} \boldsymbol{S}(k)\right\}\right]}{\mathbb{E}^{\mathcal{P}}\left[\exp \left[-\gamma\left\{F-\boldsymbol{\theta}_{\mathrm{B}}{ }^{\prime} \boldsymbol{S}\right\}\right]\right]}, \quad \forall k .
$$


ここで, $\theta_{\mathrm{B}} \in \mathcal{R}^{\mathrm{N} \times 1}$ は無裁定条件式 (3) に対する Lagrange 乗数である. 売手についても同様に, KL 情報 量制約付き事業価格最大化問題の最適性条件から, 売 手にとっての最適 $\operatorname{SDF} \Lambda_{\mathrm{S}}^{*}$ が導出できる.

事業価格の最小值 (買手価格), 最大值 (売手価格) は, 各取引主体の最適 SDF を用いた以下の式で計算で きる.

$$
C_{\mathrm{B}}=\mathbb{E}^{\mathcal{P}}\left[\Lambda_{\mathrm{B}}^{*} F\right], \quad C_{\mathrm{S}}=\mathbb{E}^{\mathcal{P}}\left[\Lambda_{\mathrm{S}}^{*} F\right] .
$$

\section{(3) 双対問題一拡張 super-hedging 問題}

買手の $\mathrm{SDF}(6)$ を問題 $\left[\mathrm{P}_{\mathrm{B}}\right]$ の Lagrangian に代入し て整理すれば，以下の双対問題が得られる.

$$
\begin{gathered}
{\left[\mathrm{D}_{\mathrm{B}}\right] \quad \max _{\boldsymbol{\theta}_{\mathrm{B}}}-\frac{1}{\gamma} \ln \mathbb{E}^{\mathcal{P}}[\exp [-\gamma \mathcal{W}]]+\boldsymbol{\theta}_{\mathrm{B}}{ }^{\prime} \boldsymbol{s}} \\
\text { s.t. } \mathcal{W}(k) \equiv F(k)-\boldsymbol{\theta}_{\mathrm{B}}{ }^{\prime} \boldsymbol{S}(k), \quad \forall k,
\end{gathered}
$$

問題 $\left[\mathrm{D}_{\mathrm{B}}\right]$ に対しては, 以下のような経済学的解釈を与 えられる. まず, 買手が期首にポートフォリオ $\theta_{\mathrm{B}}$ を空 売りして得た収入 $\boldsymbol{\theta}_{\mathrm{B}}{ }^{\prime} \boldsymbol{s}$ で事業権を購入し, 期末に事業 収益 $F(k)$ からポートフォリオの買戻費用 $\boldsymbol{\theta}_{\mathrm{B}}{ }^{\prime} \boldsymbol{S}(k)$ を支 払うとしょう。このとき, $W(k) \equiv F(k)-\boldsymbol{\theta}_{\mathrm{B}}{ }^{\prime} \boldsymbol{S}(k)$ は, 買手の期末での富を表す。次に, 取引主体が富 $x$ に対 して, 絶対危険回避度一定 (CARA: Constant Absolute Risk Aversion) 型の効用関数 $\mathcal{U}(x) \equiv-\exp [-\gamma x]$ を 持つと仮定し, 確率的な富 $\{\mathcal{W}(k)\}$ に対する確実性 等価 (CE: Certainty Equivalent) $\mathcal{W}^{\mathrm{CE}}$ を $\mathcal{U}\left(\mathcal{W}^{\mathrm{CE}}\right) \equiv$ $\mathbb{E}^{\mathcal{P}}[\mathcal{U}(\mathcal{W})]$ として定義する. これを $W^{\mathrm{CE}}$ について解 けば, 以下の式を得る。

$$
\mathcal{W}^{\mathrm{CE}}=-\frac{1}{\gamma} \ln \mathbb{E}^{\mathcal{P}}[\exp [-\gamma \mathcal{W}]] .
$$

これより, 双対問題 $\left[\mathrm{D}_{\mathrm{B}}\right]$ は，期首の富 $\boldsymbol{\theta}_{\mathrm{B}}{ }^{\prime} \boldsymbol{s}$ と $(\mathrm{CE}$ で 測った) 期末の富 $W$ CE の和を最大化するようなポー

トフォリオ問題と解釈できる.

ここで, EMM 推定問題 $\left[\mathrm{P}_{\mathrm{B}}\right]$ と効用最大化問題 $\left[\mathrm{D}_{\mathrm{B}}\right]$ の双対関係を確認しておこう. 双対問題 $\left[\mathrm{D}_{\mathrm{B}}\right]$ のポー トフォリオ戦略 $\boldsymbol{\theta}_{\mathrm{B}}$ は, 主問題 $\left[\mathrm{P}_{\mathrm{B}}\right]$ の無裁定条件 (3) の Lagrange 乗数である. 一方, 主問題 $\left[\mathrm{P}_{\mathrm{B}}\right]$ の SDF (Arrow-Debreu 状態価格) $\left\{\Lambda_{\mathrm{B}}(k)\right\}$ は, 双対問題 $\left[D_{\mathrm{B}}\right]$ の self-financing 条件 (8) の Lagrange 乗数となっている. これより，本手法は，無裁定原理に基づく EMM 推定 問題と, 効用最大化原理に基づくポートフォリオ選択 問題とを双対関係として結びつけたものであると言 える.

さらに，前節で述べたように，双対問題 $\left[D_{B}\right]$ にお ける事業取引主体の絶対危険回避度 $\gamma$ は, 主問題 $\left[\mathrm{P}_{\mathrm{B}}\right]$
の KL 情報量制約の Lagrange 乗数であり，その值は, $\mathrm{KL}$ 情報量の下限 $\hat{H}$ と 1 対 1 の関係にあることに注意 されたい. このことは，KL 情報量の下限 $\hat{H}$ をパラメ タとして与える際に, 様々な実証研究で確認されてい る危険回避度 $\gamma$ の妥当なオーダーを活用できることを 示唆している.

\section{（4）数值計算例一有料道路事業売却権}

前節までで示した主問題と双対問題の関係は, 連続 時間-連続状態の枠組, および買手が権利行使タイミン グを選択できる状況へも一般化できる. そして, 筆者 らは，この関係を活用することで，オプション価格の 具体的な計算方法を開発している ${ }^{20,21)}$. 本節では, こ の解法を用いた数值計算例を示そう. その対象として 想定するのは, 時々刻々変動する交通量に応じて事業 収益が変動するような有料道路事業を, $[0, T]$ の事業期 間中にいつでも売却できる権利 (American put option) である．例えば, BOT (Build-Operation-Transfer) 型の 有料道路事業契約において, 請負者が発注者に事業を 売却するタイミングを選択できる場合がこれに該当 する. 本節では, 解の性質をより明らかにするために 以下の 2 つ仮定を置く：まず，資産市場において 1 種類の安全資産と, 1 種類の “代表的” な危険資産の みが取引されているとする. 次に, 当該有料道路運用 事業の価值 ${ }^{* 1}$ の確率的変動と危険資産の価格の確率的 変動と相関係数が所与の定数 $\eta$ で与えられるとする. $\|\eta\|=1$ の場合は事業価値 (ひいては売却権価格)の変 動を市場資産価格で完全にヘッジできる完備市場を意 味し, $\eta=0$ の場合は市場資産取引で事業価值の変動 をヘッジすることが全くできない状況を表わす。

図-1 は, 横軸に上述の相関係数 $\eta$ を, 縦軸に事業売 却権の売手・買手価格をプロットしたものである. 図 中の 8 本の曲線の内, 上側の 4 本の太い実線および点 線は売却権の保有者 (買手) が売却タイミングが選択で きる場合 (American option) の価格, 下側の 4 本の細線 はタイミング選択が無い場合 (European option) の価格 を表わす。それぞれの場合について，実線は売手・買 手のリスク回避度 $\gamma$ が比較的高い場合で, 点線は $\gamma$ が 比較的低い場合を表わ寸，それぞれの売手・買手価格 を表わしている.

この図より，以下の 2 つのことが判る. 第 1 に，完 備市場 $(\eta=1)$ を仮定した従来の (金融) オプション評 価手法は, 市場の不完備性を考慮した本手法に対し,

\footnotetext{
*1 本来，この有料道路の価値は，道路料金と交通需要が決定つ けるキャッシュ・フロー流列の期待純現在価値として, 予め 計算しておく必要がある.
} 


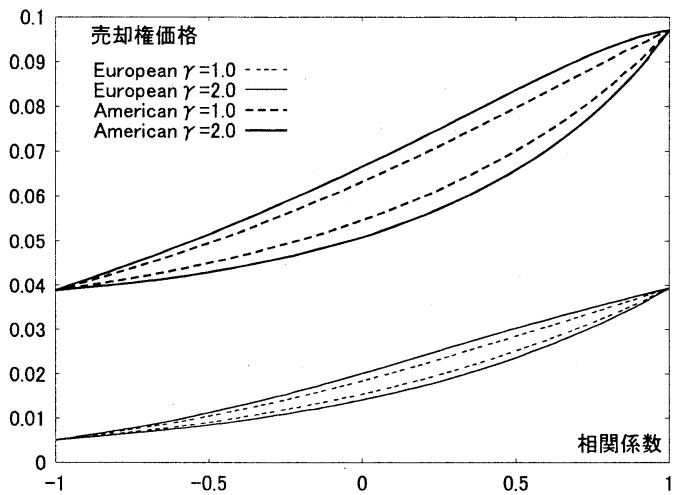

図 1 事業価值と資産価格の相関係数と売却権価格

(買手価格, 売手価格共に) 過大評価となる傾向にある. これは, 従来の手法が不完備市場リスク (i.e., 資産取 引でヘッジし切れないリスク) を完全に無視しており， それらが取引主体の危険回避性向を通じて取引価格に 及ぼす影響を考慮できていないことを示唆する．第 2 に, 相関倸数の絶対值 $\|\eta\|$ が小さく危険回避度 $\gamma$ が大 きいほど, 売却権の買手価格と売手価格との差が増加

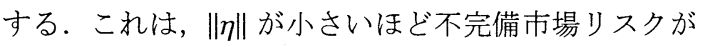
大きくなり， $\gamma$ が大きいほど, この不完備市場リスク に対して各取引主体が “感じる”費用 (プレミアム)が 増加することを反映している.

（5） あいまい性回避性向と robust 期待効用アプロー 于

前節までで示した KL 情報量制約アプローチは, 近年, 資産評価理論の実証分析の分野で注目されて いる robust 期待効用アプローチと多くの類似点を持 つ. Robust 期待効用アプローチは，Knight 流不確実性 (Knightian uncertainty, あるいは“あいまい性”) 回避性 向を明示的に考慮した意思決定・リスク評価問題の扱 いやすい表現・分析手法として位置付けられる. 本節 では Knight 流不確実性回避の枠組および robust 期待 効用アプローチを俯瞰し, 続く(6) でこれらを採用し た最近の研究と筆者らの研究を比較しながら関連する 研究課題を述べよう.

本稿における Knight 流不確実性とは, 将来の利得が 確率的に変動する状況において, 将来の事象の生起確 率が判らないものを指す。この定義は, $\mathrm{Knight}^{26)}$ が, 確率的状況を，生起確率が既知である“リスク”と，生 起確率が未知である “(真の) 不確実性”とに分類した ことに対応する。

Ellsberg ${ }^{27)}$ は, Knight の不確実性を“あいまい 性”(ambiguity) と呼び，このような状況下では意思決
定主体がリスク回避的だけでなくあいまい性回避的 (ambiguity averse) となることを, “Ellsberg の壳” と呼 ばれる以下の心理実験によって示した.

2 つの帚 A,B を用意する．被験者には，それぞ れに赤玉と白玉が合わせて 100 個入っており， 壶 $\mathrm{A}$ については赤玉と白玉が各 50 個づつ入っ ていることを知らせる.ここで, 被験者に以下 の賭けを提案する.どちらかの婊を選び，そこ から無作為に引いた玉が赤なら 1 単位の利得を 獲得し, 白なら 1 単位の損失を被る.この場合, (主観的確率で考える限りどちらの䁝でも期待利 得は 0 であるにも関わらず) 殆どの被験者が盇 Aを選ぶ.

Ellsbergはここうしたいまい性回避性向が, von Neumann and Morgenstern ${ }^{28)}$ やSavage ${ }^{29)}$ の (単一の) 主観 的確率を用いた期待効用理論では，どのような効用関 数を仮定しても説明できないことを示している.

Knight 流不確実性 (あいまい性) 下での意思決定問 題に対する先鞭は Gilboa および Schmeidler によって 付けられた. 彼らの貢献は以下の 2 点に要約される. 第 1 に, Gilboa ${ }^{30)}$ および Schmeidler ${ }^{31)}$ は，凸な非加法 的確率 (nonadditive probability) ${ }^{* 2}$ と Choquet 積分の概 念を用いた期待効用 (CEU: Choquet Expected Utility) を導入して Savage ${ }^{29)}$ の公理系を弱めることであいま い性回避性向が説明できることを示した．第 2 に， Gilboa and Schmeidler ${ }^{32)}$ は，あいまい性回避的な意思 決定主体の行動が，以下の通常の加法的確率を用いた maxmin 期待効用 (MMEU: Maxmin Expected Utility) 最大化問題 :

[MMEU] $\max _{\boldsymbol{\theta}} \min _{Q \subset \mathcal{C}} \mathbb{E}^{Q}[U(\mathcal{W})]$, s.t. (8).

としても表現できることを示した．ここで，Qは意思 決定主体の信念 (prior，あるいは主観的確率測度)， $C$ は その集合 (set of priors) を表わす. [MMEU] は，投資家 が将来の確率的収益 $\{W(k)\}$ を“悲観的”に評価する自 らの信念 $Q$ を選び，その信念の下での期待収益を最大 化するように投資戦略 $\boldsymbol{\theta}$ を決定することを意味してい

*2 状態空間 $\Omega$ と $\Omega$ 上の代数 (algebra) $\mathcal{F}$ からなる可測空間 $(\Omega, \mathcal{F})$ 上を定義する. 関数 $\mathcal{P}: \mathcal{F} \rightarrow[0,1]$ が以下の 4 つの 条件:

$$
\begin{gathered}
\mathcal{P}(\emptyset)=0, \quad \mathcal{P}(\Omega)=1 \\
A \subseteq B \Rightarrow \mathcal{P}(A) \leq \mathcal{P}(B), \forall A, B \in \mathcal{F} \\
\mathcal{P}(A \cup B)+\mathcal{P}(A \cap B) \geq \mathcal{P}(A)+\mathcal{P}(B) \\
\text { を満たすとき, } \mathcal{P} \text { は凸な非加法的確率と呼ばれる. }
\end{gathered}
$$


る. なお, $\mathrm{CEU}$ は適切な信念集合 $C$ の下での $\mathrm{MMEU}$ と等価となることが知られている (例えば尾崎 $\left.{ }^{33}\right)$.

問題 [MMEU] は, Epstein and Wang ${ }^{34)}$ によって多時 点の枠組八拡張され, さらに, Chen and Epstein ${ }^{35)}$ に よって連続時間-連続状態の枠組へと一般化された. こ れにより, MMEU アプローチは，概念的・抽象的な枠 組での定性的分析に留まらず，現実的なファイナンス 理論の枠組における定量的分析へとその適用範囲を広 げている.

さて，問題 [MMEU]においてはどのように信念集合 $C$ を決定するかが鍵となる. Hansen and Sargent ${ }^{36)}$ や Anderson ら $^{37)}$ が提案した Robust 期待効用アプロー チ (REU: Robust Expected Utility) は，この信念集合を 客観的確率測度と, 確率測度間の “距離” の概念を用い て定義することで, 数理的にも数值的にも取り扱いを 容易にした手法と見なせる. このアプローチでは, 信 念集合を以下のように定義する.

$$
\mathcal{C}(\mathcal{P}, \bar{H}) \equiv\{Q \mid \mathcal{E}(Q, \mathcal{P}) \leq \bar{E}\} .
$$

ここで, $P$ は, 何らかの方法で推計された客観的確率 測度である. $\mathcal{E}(Q, \mathcal{P})$ はP と信念 $Q$ との閒の相対エン トロピーであり, 以下の式で定義される.

$$
\mathcal{E}(Q, \mathcal{P}) \equiv-\mathcal{H}(Q, \mathcal{P})=\mathbb{E}^{Q}\left[\ln \frac{\mathrm{d} Q}{\mathrm{~d} \mathcal{P}}\right]=\mathbb{E}^{\mathcal{P}}[\Lambda \ln \Lambda] .
$$

信念集合に式(10) を採用した [MMEU] は, 客観的確 率測度と信念との距離 $H(Q, \mathcal{P})$ にパラメタ $1 / \xi$ を乗じ て目的関数に加えた以下の問題

$$
\text { [REU] } \max _{\theta} \min _{Q} \mathbb{E}^{Q}[U(\mathcal{W}(\theta))]+\frac{1}{\xi} \mathcal{E}(Q, \mathcal{P}) .
$$

と 1 対 1 の関倸にあることが知られている ${ }^{38)}$.ここ

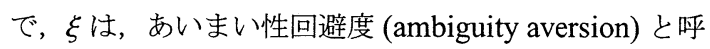
ばれ，投資家が客観的確率測度 Pおよびその根拠とな るデータやモデルをどれだけ信用しているか(あるい は客観確率 $\mathcal{P}$ と乘離した信念 $Q$ を持つことへの不効 用の大きさ)を表わすパラメタと解釈できる $\xi \rightarrow 0$ と なるとき, 投資家は客観的確率 $\boldsymbol{P}$ を信念として採用し, $\xi \rightarrow \infty$ となるとき, 投資家はあり得る確率測度の中で 最悪のものを信念として選ぶ. この故, 問題 [REU] の 枠組みは, Savage ${ }^{29)}$ 型の単一信念 (single prior) 期待効 用モデルを特殊ケースとして含む，一般化された枠組 と見なせる。

(6) 本研究との位置付けと今後の研究課題

前節で示したあいまい性回避性向および REU (Robust Expected Utility) アプローチについては, 近年, 意
思決定科学の分野のみならず, 多くの分野で理論の 精緻化および実証的知見の蓄積が盛んに行なわれて いる. 本節では, これらの研究に対する筆者らの研究 の位置付けを確認し, 関連する今後の研究課題を述べ よう.

第 1 に，筆者らが提案した不完備市場での“相対的” IP 価格評価手法に対し, マクロ経済動学の分野では, (代表的消費者均衡概念に基づいた) “絶対的” 価格評 価モデルにあいまい性回避性向の概念を組み込んだ モデル (以下, CAPM-A: CAPM under Ambiguity) を用 い, その含意を分析する研究が盛んに行なわれてい $3^{34,35,39,40,41,42)}$. これらの研究では, 収益が (Knight の意味で) 不確実な資産に対して投資家が要求する“ あいまい性プレミアム”によって, 資産市場で観測さ れる各種の puzzle— equity premium puzzle, resk-free rate puzzle, etc. 一を説明し得ることが示されてい る.ここで, 投資家が REU 最大化原理に従うとき のポートフォリオ選択問題 [REU] は, 本研究で示し た買手の行動 $\left[P_{B}\right]$ に良く似た数理的構造を持つ. 事 実, 問題 $[R E U]$ の主観的確率 $Q^{*}$ と客観確率 $\mathcal{P}$ 間の Radon-Nikodym 微分 $\Lambda \equiv \mathbb{E}^{\mathcal{P}}[\mathrm{d} Q / \mathrm{d} \mathcal{P}]$ は, 式(6) と同 様の Logit 式で表わされる. この故, 筆者らの提案手 法 ${ }^{21,23)}$ を活用することで, CAPM-A に対する効率的 数值解法を開発できるだろう.

ただし，筆者らのモデル $\left[\mathrm{P}_{\mathrm{B}}\right]$ と CAPM-A とは, 数 学的性質こそ似ているものの, それぞれの目的および 用途が異なる点には注意が必要である. 筆者らのモデ ルは, 事業権 (オプション)の売手・買手が, 各主体の “ミク口的” な行動原理に従うときの事業価格の上限・ 下限を, 無裁定原理と取引主体のリスク選好に基づい て求めるものである. 一方, CAPM-A は, 市場に参入 する無数の投資家を代表的個人として“マク口的”に 表現し，その消費・投資行動の均衡状態として (当該 事業を含む) 全ての資産価格を一意に決定する. 技術 的には, CAPM-A には無裁定原理は明示的に考慮さ れておらず, 問題 [REU] で求められる信念と, 筆者の 手法で求められるリスク中立確率とが一致する保証は ない (i.e., 問題 $[R E U]$ の解 $Q$ の下で, 任意の資産価格 が martingale になるとは限らない). この点に留意す れば, 筆者らのアプローチは, 無裁定原理を明示的に 考慮した CAPM-A モデルの構築および分析手法の開 発といった方向にも活用し得る.

第 2 に, REU および筆者らの KL 情報量アプロー チは，IP 方直面するリスク管理における好ましいリ スク測度の開発にも活用し得る. 従来, こうしたリ 
スク測度に関する議論はファイナンス分野において 活発に行なわれてきた．特に，金融リスク管理にお いて最も重要な測度の一つとして浸透してきた VaR $\left(\right.$ Value at Risk) $\left.{ }^{43}\right)$ が，整合的なリスク測度 (coherent risk measure $)^{44,45)}$ としての要件を満たさないことが 明らかにされて以来, 新たなリスク測度が数多く提 案されている 44, 45, 46, 47, 48,49). こうしたリスク測度の 一つとして，(3) 節で示した確実性等価 (CE: Certainty Equivalent) や, それを動学的な枠組一拡張したもの ${ }^{47)}$ が存在する。このことは，筆者らの研究が，リスク測 度の開発とその計量方法として活用し得ることを示唆 している.

第 3 に, 近年, ゲーム理論においても，このあいまい 性の概念を導入した研究が進められている.これらの 研究の多くは, ゲーム理論の枠組に CEU 原理 ${ }^{50,51,52)}$ あるいは MMEU 原理 53,54) を導入し，Nash 均衡の概 念を一般化している。こうした“あいまい性ゲーム” と古典的ゲームの枠組の関係は, 例えば, Eichberger and Kelsey55) などで整理されている.しかし，本稿で 解説したような REU 原理をゲーム理論に導入した研 究は，筆者らの知る限り存在せず，REU アプローチが 持つ数理的な取り扱い易さが，十分に活用されていな いように見える。そのため，本稿で紹介した REU の 概念を導入したゲームの枠組の構築は, 今後の研究課 題となり得よう。なお, 近年, 土木計画分野において は, PFI 事業などの契約問題 ${ }^{56,57)}$ に対して, ゲーム 理論を用いた分析を行なう研究が進められている。こ うした方向の研究にも, 上述のあいまい性ゲームや, REU ゲームなどの概念は応用できるだろう．

最後に，近年，IPに対して，防災に対する取り組み の必要性, 重要性が要請されている. 地震や台風など の自然災害は, 本質的に, 過去の経験やデータ不足か ら，その発生頻度や被害規模にあいまい性が存在する と考えられる。このような状況下での合理的な(ある いは robust な) 意思決定問題に対して MMEU や REU アプローチを用いることは，ごく自然である。また， あいまい性回避性向の概念は，通常の危険回避性向の みでは説明し切れない災害再保険やキャット・ボンド (catastrophe-linked bond) のプレミアムを説明する理論 的枠組として活用できる. そして，筆者らの研究成果 は, これらの問題の数理特性の分析や定量的手法の開 発に活用できるだろう.

\section{4 オプション・グラフ : 複雑な連鎖的 構造を持つ投資意思決定問題}

本章では，赤松・長江 ${ }^{23)}$ および長江・赤松 22) で提 案したオプション・グラフ・アプローチを解説する. 本章は，以下のように構成される：まず，(1)においい てオプション・グラフの基本的考え方を述べる. 続く (2)〜(6) では，対象とするオプション構造を限定した 上で, モデルの定式化, 数理解析, および数值解法に ついて解説する : (2) ではオプション・グラフ問題の定 式化を行ない, (3)において, この問題の最適性条件を 一般化相補性問題 (GCP: Generalized Complementarity Problem として記述する; (4) では, 離散的枠組の下 で, 最適性条件を有限次元 GCP として表現する; (5) では，この有限次元 GCP がより小規模なサブ問題一 分解できることを示し，それを活用した効率的解法の 考え方を述心゙る; (6) ではこの解法を用いた数值計算例 を示す．最後に，(7) では，GCPアプローチを用いた 他の研究課題を紹介する.

\section{(1) オプション・グラフの基本的考え方}

筆者らの研究 ${ }^{23,22)}$ が対象とする複合リアル・オプ ションは, 以下のように定義される:時々刻々確率的に 変化する状態 (e.g., 交通量, 貨物取扱量, 為替, 財価格 など) に応じてフィードバック的にアクティビティを 変更することでキャッシュ・フロー流列をコントロー ルできる権利。ここで，アクティビティとは，ある特 定の経済活動を行っている状態を指す，例えば，最も シンプルなリアル・オプションとして, 有料道路事業 において, 交通需要の増加に応じて 1 度だけ道路容量 を拡張できる状況を考えてみよう。この場合, 当該事 業は, 「容量拡張前 (現状, $\mathrm{X}$ で記述)」と「容量拡張後 ( $\mathrm{Y}$ と記述)」という2 つのアクティビティと, 道路を 拡張できる $(\mathrm{X}$ から Y ヘアクティビティを変更できる) オプションから構成されると見なせる，管理者 (オプ ション所有者) は，この拡張にかかる費用 (サンク・コ スト)を支払ってオプションを行使することで，より 多くの交通需要 (ひいては当該道路からの料金収入)を 獲得できる，そして，一度道路を拡張した後は，元の 状態に戻す (i.e., アクティビティを Y から X へ変更す る)ことはできない.このような一度きりのタイミン グ選択問題の意思決定構造は, 図-2 a) のように, アク

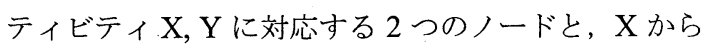
Yへの有向リンクとして表現できる. 以下では，この 構造を単位オプション構造と呼ぶ.

一般に, 多くのプロジェクト意思決定は, タイミン グ選択のみならず，様々な柔軟性を持ち，不可逆的な 


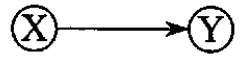

a) 単位構造

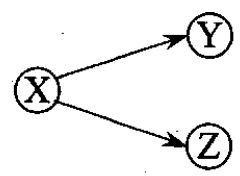

c) 分岐構造

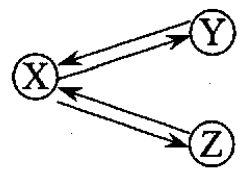

e）サイクルー分妓構造

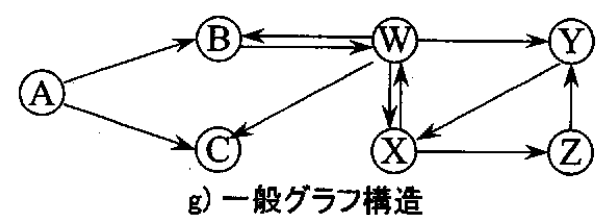

図 2 オプション構造の分類

ものと可逆的なものが混在している. 従来, こうした 柔軟性や不可逆性/可逆性を扱うために, 様々なリア ル・オプションが提案されてきた。これらのリアル． オプションの権利行使構造は, いずれも, 上述の単位 オプション構造を組み合わせた有向グラフとして表現 できる.このオプション構造に着目することで, 従来 研究が対象としてきた様々なリアル・オプション問題 を，以下の 6 つのカテゴリに分類できる.

I) 単位オプション 一度きりの意思決定について, そ のタイミングのみが選択できるオプション，意 思決定の種類 (e.g., 投資, 参入, 拡張, 縮小, 廃 㶳, 撤退)によらず, 殆どのリアル・オプション がこのカテゴリに分類される.

II) タンデム型オプション ある意思決定を行なうこと で，新たに別のオプションを獲得できるもの. タンデム型オプションの構造は, 図-2 b) の上 うに, 複数の単位オプションが直列に連結した グラフとして表現される. このカテゴリに分類 されるオプションとして, ファイナンス分野で は Geske ${ }^{58)}$ の複合オプションが举げられる.リ アル・オプションの分野では, 新技術採用オプ ション ${ }^{59,60,61)}$ や多段階オプション (multi-stage option) ${ }^{62)}$ などがこのカテゴリに分類される.

III) 分岐型オプション 意思決定を行なう際に, 権利行
使のタイミングのみならず, 変更先のアクティ ビティを複数の候補の中から選択できるもの. この権利行使は排他かつ不可逆的であり，いず れかの権利が行使されると同時に他のオプショ ンは失われる. 分岐型オプションの構造は, 図一 $2 \mathrm{c})$ のうに, 複数の単位オプションが始点ア クティビティを共有したグラフとして表現され る.このカテゴリに分類されるオプションとし ては, Margrabe' ${ }^{63)}$ の交換オプション, Stulz ${ }^{64)}$ の最小最大值オプションが挙げられる.

IV) サイクル型オプション 一度行使した権利を, 別の 意思決定を行なうことで再び獾得できる (i.e., 意 思決定が可逆的) もの. サイクル型オプション の構造は, 図-2d)のように, $2 つ$ (以上)の単位 オプションからなるサイクル構造として表現さ れる.このカテゴリに分類されるオプションと して, Dixit ${ }^{65)}$ や Dixit and Pindyck ${ }^{66)}$ の参入・ 撤退オプションや，一時停止-操業再開オプショ ンなどが挙げられる.

V) 分岐・サイクル複合型オプション III) と IV)の複 合型で, その構造は図-2 e) のように表現され る. Dixit and Pindyck ${ }^{66)}$ の参入・撤退・一時停止 オプションなどがこのカテゴリに分類される.

VI) 完全グラフ型オプション 任意のアクティビティ 間を切り替え可能 (i.e., あらゆる意思決定が可 逆的)であるもの.このオプションの構造は 図-2f)のような完全グラフ (全てのノード間に リンクが存在するグラフ) として表現される. このカテゴリに分類されるオプションとして, Kulatilaka ${ }^{67)}$ が挙げられる.

こうして分類されたオプション問題に対して，筆 者らの研究 ${ }^{23,22)}$ は以下のように位置付けられる. ま ず, 上述のように異なる構造を持つ様々なリアル・オ プション問題が，いずれも，一般化相補性問題 (GCP: Generalized Complementarity Problem) として統一的 に記述できることを明らかにした，これによって，問 題ごとに特殊な仮定をおいて個別の分析手法を提案し ていた従来のリアル・オプション問題に対し，よりー 般的な状況の下で, 首尾一貫した数值計算法を確立し た.さらに，オプション構造が，図-2 g)に示すような サイクルを含む一般的な有向グラフで表現される “オ プション・グラフ”問題に対して，見通しの良い記述・ 分析のための枠組を構築した. 


\section{(2) 定式化}

本節では, オプション・グラフ問題の定式化を, 図-3 のような構造を持つオプションを例として説明 しよう.オプション・グラフ・モデルは, 以下の 3

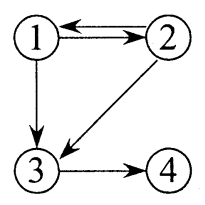

図 3 オプション・グラフ例

つの仮定から構成される. 第 1 に, 事業 (オプショ ン・グラフ) を構成するアクティビティ集合を $N \equiv$ $\{1,2,3,4\}$, それらを切り換えるオプション集合を $L \equiv$ $\{(1,2),(1,3),(2,1),(2,3),(3,4)\}$ とする. 第 2 に, 事業 のキャッシュ・フロー流列を変動させる確率的要因 (e.g., 金利, 為替, 財価格など) を状態変数 $P \in \mathcal{R}$ と して集約的に表現し，そのプロセスが図-4 に示すよ うな確率過程に従うとする。この図は, 横軸に時間 $t$,

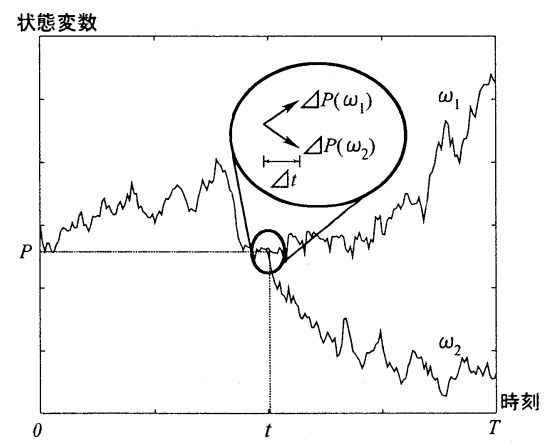

図 4 状態変数のサンプル・パス

縦軸に状態変数 $P(t)$ を取り, $[0, t]$ 間の状態変数プロ セス $\{P(s) \mid s \in[0, t]\}$ を共有する 2 つのサンプル・パス $\omega_{1}, \omega_{2}$ をプロットしたものである. 時刻 $t$ において状 態変数 $P(t)=P$ が観測されたとき, 微小時間 $\Delta t$ 中の 状態変数の変化量 $\Delta P \equiv P(t+\Delta t)-P$ は, 以下の (単位 時間当りの) 期待值と分散 :

$$
\begin{aligned}
& \alpha(t, P, n) \equiv \mathbb{E}[\Delta P] / \Delta t, \quad \forall(t, P, n) \\
& \sigma(t, P, n) \equiv \operatorname{Var}[\Delta P] / \Delta t, \quad, \quad
\end{aligned}
$$

を持つ確率変数として表わされる.すなわち, 状態変数 のプロセスを特定化することは, 任意の時刻と状態変数 について, その状態変数の期待増分 $\alpha:[0, T] \times \mathcal{R} \times N \rightarrow$ $\mathcal{R}$ と, 確率的なバラツキの大きさ $\sigma:[0, T] \times \mathcal{R} \times N \rightarrow$ $\mathcal{R}_{+}$を与えることと等価である. 筆者らの枠組では, ア クティビティごとに，これらの $\alpha$ や $\sigma$ が異なるよう
な一般的な状況——例えば,（1）に挙げた有料道路拡 張事業において, 当該路線の日交通量を状態変数 $P(t)$ とする場合, 「道路拡張前 $(\mathrm{X})$ 」と「道路拡張後 $(\mathrm{Y})$ 」 の 2 つのアクティビティについて自然に想定される, $\alpha(t, P, X)<\alpha(t, P, Y)$ という状況——を扱える*3. 最後 に, 事業から発生するキャッシュ・フローは, 毎時刻発 生する利潤フローと, アクティビティを切り替える瞬 間に発生する費用 (サンク・コスト) の 2 種類とする. この内, 前者については, 時刻 $t$ で発生する単位時間 あたりの利潤を, その時に選択されているアクティビ ティ $n(t)=n$, および状態変数 $P(t)=P$ についての所 与の関数 $\pi(t, P, n)$ として定義する. 後者については, アクティビティを $n$ から $m$ に切り換えるための費用 (以下, 切り替え費用) を, 定数 $C_{n, m}$ で与える.

この枠組下で, 事業の管理者 (オプション・グラフの 保有者) は, 期間 $[0, T]$ に当該事業から発生するキャッ シュ・フロー流列の期待純現在価值 (ENPV: Expected Net Present Value) の総和を最大化するように, アク ティビティ戦略 $\{n(t) \mid t \in[0, T]\}$ を決定する.これは以 下のように定式化される：

$$
\text { [P] } \max _{\{n(t) \mid t \in[0, T]\}} \mathbb{E}\left[\mathcal{J}\left(0, T,\{n(t)\}_{t=0}^{T}\right) \mid\left(P_{0}, n_{0}\right)\right]
$$

ここで, $\mathcal{J}\left(t, T,\{n(s)\}_{s=t}^{T}\right)$ は, 期間 $[t, T]$ にアクティビ ティ戦略 $\{n(s) \mid s \in[t, T]\}$ の下で得られるキャッシュ・ フロー流列を, 所与の割引率 $\rho$ で時刻 $t$ まで割り引い た現在正味価值であり, 以下の式で定義される：

$$
\begin{aligned}
& \mathcal{J}\left(t, T,\{n(s)\}_{s=t}^{T}\right) \\
& \equiv \int_{t}^{T} e^{-\rho(s-t)}\left\{\pi(s, P(s), n(s))-\sum_{k} \delta_{k}(s) C(k)\right\} \mathrm{d} s .
\end{aligned}
$$

$\mathbb{E}[\cdot(P, n)]$ は, 時刻 $t$ に状態変数 $P(t)=P$ が観測され た時にアクティビティ $n(t)=n$ が選択されている条件 の下での条件付期待演算子である. 式 (13)において, $K \equiv\{1,2, \cdots$,$\} は, アクティビティ変更のインデクス$ であり, 戦略 $\{n(t)\}$ によって決定される. $\delta_{k}(t)$ は時刻 $t$ に $k$ 番目のアクティビティ変更が行なわれたときに のみ 1 , それ以外で 0 となるデル夕関数， $C(k)$ はその 時の切り換え費用を表す.

\section{（3）一般化相補性問題としての最適性条件の表現}

本節では問題 [P] の最適性条件が一般化相補性問 題 (GCP: Generalized Complementarity Problem) とし

\footnotetext{
*3この点は典型的なリアル・オプション研究 (例えば, Dixit and Pindyck $\left.{ }^{19)}\right)$ にはない特徽である.
} 
て表現できることを示そう. まず, 問題 $[\mathrm{P}]$ の最適值 関数を,

$$
\begin{gathered}
V_{1}(t, P) \equiv \max _{\{n(s) \mid s \in[t, T]\}\}} \mathbb{E}\left[\mathcal{J}\left(t, T,\{n(s)\}_{s=t}^{T}\right) \mid(P, 1)\right], \\
\vdots \\
V_{4}(t, P) \equiv \max _{\{n(s) \mid s \in[t, T]\}\}} \mathbb{E}\left[\mathcal{J}\left(t, T,\{n(s)\}_{s=t}^{T}\right) \mid(P, 4)\right]
\end{gathered}
$$

と定義する. それぞれの最適值関数 $V_{n}(t, P)$ は, 時刻 $t$ においてアクティビティ $n$ が選択されている条件の 下で，それ以降 $[t, T]$ に発生するキャッシュ・フロー 流列の ENPV の最大值を表している. 以下では, この $V_{n}(t, P)$ をアクティビティ $n$ の価值と呼ぶ. こうして 定義された, それぞれのアクティビティ価值 $V_{n}(t, P)$ に対して DP (Dynamic Programming) 原理を適用する ことで，任意の状況下での最適戦略を記述できる.

まず，アクティビティ 1 が選択されているとき, DP 原理を適用すれば，管理者の意思決定は，以下の 3 つ から最も高い価值をもたらすものを離散的に選択する 問題に帰着する：(1)微小時間 $\Delta$ だけアクティビティ 1 を継続する ; (2)切り換え費用 $C_{1,2}$ を払ってアクティ ビティを 2 に変更する ; (3) $C_{1,3}$ を支払ってアクティビ ティを 3 に変更する.これより, アクティビティ 1 の 価値は,

$$
\begin{array}{r}
V_{1}(t, P)=\max .\left\{\pi(t, P, 1) \Delta+e^{-\rho \Delta} \mathbb{E}\left[V_{1}(t+\Delta, P+\Delta P)\right],\right. \\
\left.V_{2}(t, P)-C_{1,2}, \quad V_{3}(t, P)-C_{1,3}\right\}
\end{array}
$$

を満足する*4. 右辺の最大值演算内の各項は以下のよ うに解釈される：第 1 項はアクティビティ 1 を継続し た時の価值であり， $\Delta$ 間の収入と $\Delta$ 後のアクティビ ティ価值の ENPV の和で表される. 第 2, 第 3 項はア クティビティを 2 もしは 3 人切り換えた時の純価值 (i.e., 変更先の価值から切り換え費用を引いたもの) で ある.この式の左辺から右辺を引き， $\Delta \rightarrow 0$ として整 理すれば, HJB (Hamilton-Jacobi-Bellman) 方程式 :

$$
\min .\left\{F_{1,1}\left(V_{1}\right), F_{1,2}\left(V_{1}, V_{2}\right), F_{1,3}\left(V_{1}, V_{3}\right)\right\}=0
$$

を得る.ただし，時刻と状態変数に関する記述を省略 した.ここで,

$$
F_{n, n}\left(V_{n}\right) \equiv-\mathcal{L}_{n} V_{n}(t, P)-\pi(t, P, n), \quad \forall n \in N,
$$
$F_{n, m}\left(V_{n}, V_{m}\right) \equiv V_{n}(t, P)-V_{m}(t, P)+C_{n, m}, \quad \forall(n, m) \in L$

*4ここでは, 数学的な愋密さを犠牲にする代わりに, 真感的な 理解を得やすい表現を用いた. より詳細な最適性条件の導出 は, 筆者らの研究 $23,22,68)$ を参照されたい.
である. $\mathcal{L}_{n}$ は状態変数プロセスから決定される偏微 分演算子で，以下の式で定義される：

$$
\mathcal{L}_{n} \equiv \frac{\partial}{\partial t}+\alpha(t, P, n) \frac{\partial}{\partial P}+\frac{1}{2}\{\sigma(t, P, n)\}^{2} \frac{\partial^{2}}{\partial P^{2}}-\rho
$$

ただし， $\alpha, \sigma$ は, 式(12) で状態変数プロセスを特徵付 ける外生的な関数である.

同様に，時刻 $t$ でアクティビティ 2 あるいは 3 が選 択されている場合の最適性条件は，それぞれ，

$$
\begin{gathered}
\min .\left\{F_{2,2}\left(V_{2}\right), F_{2,1}\left(V_{2}, V_{1}\right), F_{2,4}\left(V_{2}, V_{4}\right)\right\}=0, \\
\min .\left\{F_{3,3}\left(V_{3}\right), F_{3,4}\left(V_{3}, V_{4}\right)\right\}=0
\end{gathered}
$$

で表される. 最後に, アクティビティ 4 が選択されて いる場合は，現在のアクティビティを継続する以外の 選択肢が無いため, 最適性条件は, 以下の線形方程式

$$
F_{4,4}\left(V_{4}\right)=0
$$

として表される.

時刻 $t$ の各状態 $P$ において, どのアクティビティ が選択されているかを事前に決定しておくことは できないため, 問題 [P] は, 上記 4 つの最適性条件 (16)(18)(19)(20) を, 全ての時刻 $t \in[0, T]$ および状態 変数 $P \in \mathcal{R}$ について連立させた以下の GCP として表 現できる.

[GCP0] Find $\{\boldsymbol{V}(t, P) \mid(t, P) \in[0, T] \times \mathcal{R}\}$ such that

$$
\left\{\begin{array}{l}
\min .\left\{F_{1,1}(\boldsymbol{V}(t, P)), F_{1,2}(\boldsymbol{V}(t, P)), F_{1,3}(\boldsymbol{V}(t, P))\right\}=0, \\
\min .\left\{F_{2,2}(\boldsymbol{V}(t, P)), F_{2,1}(\boldsymbol{V}(t, P)), F_{2,4}(V(t, P))\right\}=0, \\
\min .\left\{F_{3,3}(\boldsymbol{V}(t, P)), F_{3,4}(\boldsymbol{V}(t, P))\right\}=0, \\
F_{4,4}(\boldsymbol{V}(t, P))=0,
\end{array}\right.
$$$$
\forall(t, P) \in[0, T) \times \mathcal{R},
$$

ここで, $V(t, P) \equiv\left\{V_{n}(t, P) \mid n=1, \cdots, 4\right\}$ である. 本稿 では, 満期 $t=T$ においてはキャッシュ・フローが発 生しないとしているため, 問題 [GCP0] の終端条件は 以下の式で表される.

$$
V_{n}(T, P(T))=0, \quad \forall P(T) \in \mathcal{R}, \forall n \in N
$$

\section{(4) 問題の離散的表現}

問題 [GCP0] は解析解を持たないため, その数値解 を求めるための手法を開発する必要がある. 本節で は，そのような手法の一つとして，離散的枠組を用い た数值解法を解説する.

まず, 時刻 $t$ と状態变数 $P$ を, 図 -5 のような $\mathrm{I} \times \mathrm{J}$ 格子上で 


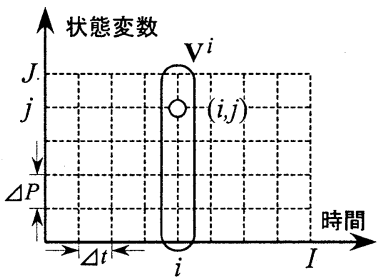

図 5 時間-状態変数空間上の離散格子

$$
t \rightarrow t^{i} \equiv i \Delta t, \quad P \rightarrow P^{j} \equiv j \Delta P
$$

と離散化する. そして，この格子上のアクティビティ 価值を $V_{n}^{i, j} \equiv V_{n}\left(t^{i}, P^{j}\right)$ および $V_{n}^{i} \equiv\left\{V_{n}^{i, j} \mid j \in 1, \cdots, \mathrm{J}\right\}$ と離散表現し, 最適性条件式 $(16) \sim(20)$ に現われる偏 微分演算子を, 以下のように離散近似する :

$$
\mathcal{L}_{n} V_{n}\left(t^{i}, P\right) \approx L_{n}^{i} V_{n}^{i}+M_{n}^{i} V_{n}^{i+1}, \quad \forall n \in N, \forall i \in I .
$$

ここで, $I=\{0, \cdots, I-1\}$ は時刻についての格子集合 である, $\boldsymbol{L}_{n}^{i}, \boldsymbol{M}_{n}^{i}$ は, $\mathrm{J}$ 次元行列で, 状態変数プロセス を特徽付汀る関数 $\alpha(t, P, n), \sigma(t, P n)$ から一意に決定さ れる.

このとき，オプション・グラフ問題 [GCP0] は，以 下の有限次元 GCP として書き直せる.

[GCP1] Find $\left\{\boldsymbol{V}^{i} \mid i \in I\right\}$ such that

$$
\left\{\begin{array}{l}
\min .\left\{\boldsymbol{F}_{1,1}\left(\boldsymbol{V}^{i}, \boldsymbol{V}^{i+1}\right), \boldsymbol{F}_{1,2}\left(\boldsymbol{V}^{i}\right), \boldsymbol{F}_{1,3}\left(\boldsymbol{V}^{i}\right)\right\}=\mathbf{0}, \\
\min .\left\{\boldsymbol{F}_{2,2}\left(\boldsymbol{V}^{i}, \boldsymbol{V}^{i+1}\right), \boldsymbol{F}_{2,1}\left(\boldsymbol{V}^{i}\right), \boldsymbol{F}_{2,4}\left(\boldsymbol{V}^{i}\right)\right\}=\mathbf{0}, \\
\min .\left\{\boldsymbol{F}_{3,3}\left(\boldsymbol{V}^{i}, \boldsymbol{V}^{i+1}\right), \boldsymbol{F}_{3,4}\left(\boldsymbol{V}^{i}\right)\right\}=\mathbf{0}, \\
\boldsymbol{F}_{4,4}\left(\boldsymbol{V}^{i}, \boldsymbol{V}^{i+1}\right)=\mathbf{0},
\end{array}\right.
$$

$\forall i \in I$,

ここで, $V^{i} \equiv\left\{V_{n}^{i} \mid n \in N\right\}$ は NJ 次元列ベクトル,

$$
\begin{aligned}
& \boldsymbol{F}_{n, n}(\cdot) \equiv-\boldsymbol{L}_{n}^{i} \boldsymbol{V}_{n}^{i}-\boldsymbol{M}_{n}^{i} \boldsymbol{V}_{n}^{i+1}-\boldsymbol{\pi}_{n}^{i}, \quad \forall n \in N, \forall i \in I, \\
& \boldsymbol{F}_{n, m}(\cdot) \equiv \boldsymbol{V}_{n}^{i}-\boldsymbol{V}_{m}^{i}+1 C_{n, m}, \quad \forall(n, m) \in L, \forall i \in L,
\end{aligned}
$$

である. また, $\pi_{n}^{i} \equiv\left\{\pi\left(t^{i}, P^{j}, n\right) \mid j=1, \cdots, \mathrm{J}\right\}$ なるべク トルであり，1 は全ての要素が 1 であるような J 次元列 ベクトルである. 問題 [GCP1] の終端条件は, 式 (21) を離散表現した以下の式で表される.

$$
\boldsymbol{V}^{\mathrm{I}}=\mathbf{0} .
$$

\section{(5) 問題の分解可能性と効率的解法}

問題 [GCP1] は, 未知変数の次元が非常に大きい $(=N \times \mathrm{I} \times \mathrm{J})$ ため, ナイーブに計算することは極めて非 効率的である，そこで，本節では，図-6のように，こ
の有限次元 $\mathrm{GCP}$ を, 異なる 2 つ座標軸—時間とグ ラフ構造一について分解しよう。これにより，[GCP1] の解を求めることを, より規模の小さいサブ問題を特 定の順序で解くことに帰着させられる.

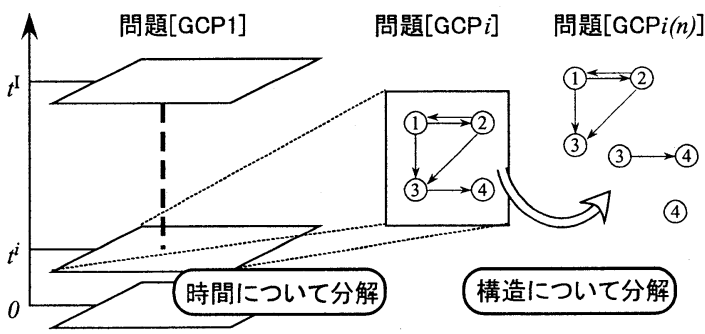

図 6 オプション・グラフ問題の分解

\section{(a) 時間についての分解}

式 (24) より, 時点 $i$ で成立すべき問題 (以下, [GCP $\left.{ }^{i}\right]$ と表記) は, 時点 $i+1$ での最適值関数 $\boldsymbol{V}^{i}$ が判ってい るならば， $V^{i}$ のみを未知変数とする独立した問題と なる、つまり，終端条件 $V^{\mathrm{T}}=\mathbf{0}$ を与件とすれば，時 点 I- 1 の問題 $\left[G C P^{I-1}\right]$ を解いて $V^{\mathrm{I}-1}$ を求められる. こうして時点を遡りながら $V^{-1}, V^{-2}, \cdots, V^{2}, V^{1}, V^{0}$ を順に求めることで, 全ての時刻における最適值関数 $\left\{\boldsymbol{V}^{i} \mid i \in I\right\}$ を計算できる.

(b) グラフ構造についての分解

各時点で解くべき問題 [GCPi] は, さらに, グラフ の構造について分解できる. まず，図-3 のアクティビ ティ4からは他のどのアクティビティにも切り換えら れないため, $V_{4}^{i}$ は, 方程式

$$
\boldsymbol{F}_{4,4}\left(\boldsymbol{V}_{4}^{i}, \overline{\boldsymbol{V}}_{4}^{i+1}\right)=-\boldsymbol{L}_{4}^{i} \boldsymbol{V}_{4}^{i}-\boldsymbol{M}_{4}^{i} \overline{\boldsymbol{V}}_{4}^{i+1}-\boldsymbol{\pi}_{4}^{i}=\mathbf{0}
$$

の解として，他のアクティビティ価值とは独立に計算 できる (ただし， $V_{4}^{i+1}$ が定数であることを明示するた めに上線付きで表現した). 次に，アクティビティ 3 か らはアクティビティ 4 へのみ切り換え可能であり，そ の価值 $V_{4}^{i}$ は (この時点では) 既知である.このため, アクティビティ 3 の価值 $V_{3}^{i}$ のみを未知変数とした以 下の GCP:

[GCP $\left.{ }^{i}(3)\right]$ Find $\boldsymbol{V}_{3}^{i}$ such that

$$
\min .\left\{\boldsymbol{F}_{3,3}\left(\boldsymbol{V}_{3}^{i}, \overline{\boldsymbol{V}}_{3}^{i+1}\right), \boldsymbol{F}_{3,4}\left(\boldsymbol{V}_{3}^{i}, \overline{\boldsymbol{V}}_{4}^{i}\right)\right\}=\mathbf{0}
$$

は, 独立に解くことができる. 最後に, アクティビティ 1 と 2 の間では (理論上) 何度でもアクティビティを 切り換えられる.そのため, これら 2 つのアクティビ ティ価值 $\boldsymbol{V}_{1}^{i}$ は $\boldsymbol{V}_{2}^{i}$ は相互に依存し合っており，以下の 連立 GCP の解として同時に計算される必要がある. 
[GCPi $(1,2)]$ Find $\left(\boldsymbol{V}_{1}^{i}, \boldsymbol{V}_{2}^{i}\right)$ such that

$$
\left\{\begin{array}{l}
\min .\left\{\boldsymbol{F}_{1,1}\left(\boldsymbol{V}_{1}^{i}, \overline{\boldsymbol{V}}_{1}^{i+1}\right), \boldsymbol{F}_{1,2}\left(\boldsymbol{V}_{1}^{i}, \boldsymbol{V}_{2}^{i}\right), \boldsymbol{F}_{1,3}\left(\boldsymbol{V}_{1}^{i}, \overline{\boldsymbol{V}}_{3}^{i}\right)\right\}=\mathbf{0}, \\
\min .\left\{\boldsymbol{F}_{2,2}\left(\boldsymbol{V}_{2}^{i}, \overline{\boldsymbol{V}}_{2}^{i+1}\right), \boldsymbol{F}_{2,1}\left(\boldsymbol{V}_{2}^{i}, \boldsymbol{V}_{1}^{i}\right), \boldsymbol{F}_{2,3}\left(\boldsymbol{V}_{2}^{i}, \overline{\boldsymbol{V}}_{3}^{i}\right)\right\}=\mathbf{0}
\end{array}\right.
$$

このように, 各時点 $i$ において, $\boldsymbol{V}_{4}^{i}, \boldsymbol{V}_{3}^{i}$, および $\left(\boldsymbol{V}_{1}^{i}, \boldsymbol{V}_{2}^{i}\right)$ をこの順番で求めることで, 全てのアクティビティの 価值を計算できる. 上述の各手順で解くべきサブ問題 は, いずれも, 未知変数の次元が高々 $\mathrm{J}$ のオーダーで しかない独立した問題であり, 後述するように, 極め て効率的に解くことができる. また，こうした時間と グラフ構造への分解, およびサブ問題を計算する順序 は，任意の構造を持つオプション・グラフに一般化で きる，その詳細については，長江・赤松 ${ }^{22)}$ を参照され たい.

オプション・グラフ問題 [GCP1] を分解して得 られるサブ問題 $\left[\mathrm{GCP}^{i}(3)\right]$ および $\left[\mathrm{GCP}^{i}(1,2)\right]$ のよ うな有限次元 GCP に対しては, 数理計画分野に おいて, その解法に関する研究が蓄積されている $69,70,71,72,73,74,75,76)$. 筆者らは, これらの知見の内, 平滑化関数 (smoothing function ${ }^{77)}$ ) アプローチの一種 として提案された Peng and $\operatorname{Lin}^{75}$ ) のアルゴリズムを用 いた解法を開発した。 そして，このアルゴリズムが， 最新の研究成果であるのみならず, サブ問題の数理的 特性を活用することで, 極めて効率的に解を求めら れることを明らかにしている. その詳細については, Nagae and Akamatsu ${ }^{68)}$ を参照されたい.

\section{(6) 数值計算例}

本節では, 提案手法の判りやすい数値計算例を示 す. その対象として想定する複合オプションは, 不確 実に変動する施設需要に応じて, 当該施設の遊休化も しくは解体が可能な不動産施設運用事業である.以下 では, まず, この事業について想定する状況を示し, 前節の解法で求めたオプション価值および最適戦略を 示す.

\section{(a) 想定する状況とオプション構造}

本節で対象とする不動産事業は, 以下の 3 つのアク ティビティから構成されるとする : まず, 施設の賃貸 が行われている施設運用アクティビティ $(\mathrm{A})$; 次に, 施 設が遊休化され, 運用再開に備えて維持管理のみが行 われている施設遊休アクティビティ $(\mathrm{S})$; 最後に, 施 設が解体され，一切のキャシュ・フローが発生しない 更地アクティビティ $(\mathrm{Q})$. このプロジェクトの意思決 定構造索，图-7に示寸有向グラフで表現する。す小才 ち，施設運用アクティビティからは，施設遊休もしく
は更地のいずれかに切り換えられるとし，施設遊休お よび更地アクティビティからは，施設運用にのみ変更 可能であるとする.

事業主体は時々刻々変動する施設需要 $P(t)$ に応じて これらのアクティビティを変更するものとする. 以下 では, 各アクティビティから発生するキャッシュ・フ ローについて述べる. まず, 施設運用状態 (A) からは, 毎時刻, 施設需要に応じた $\pi_{\mathrm{A}}(t, P)$ だけの利潤フロー が発生する. 次に, 施設遊休状態 $(\mathrm{S})$ からは, 賃貸は 行われず，運用再開に備えた遊休施設の維持費用のみ が発生する. 最後に, 更地状態 $(\mathrm{Q})$ からは, 一切の利 潤フローが発生しないとする.

本節では, 判りやすい数值計算例を示すため, 上述 の枠組に加え, 以下の仮定をおく.まず，いかなるア クティビティにおいても, 施設需要 $P(t)$ の確率的変 動が以下の $P$ のみの関数として特徵付けられるとす る*5.

$\alpha(t, P, n)=\alpha P, \quad \sigma(t, P, n)=\sigma P, \quad \forall t \in[0, T], \forall n \in N$.

ここで, $\alpha, \sigma$ は所与の定数である. 次に, 施設運用状 態 $\mathrm{A}$ および施設遊休状態 $\mathrm{S}$ から発生するキャッシュ・ フローが, それぞれ, 以下の式で表されるとする.

$$
\pi_{\mathrm{A}}(t, P)=P-E, \quad \pi_{\mathrm{S}}(t, P)=-M .
$$

ここで, $E, M$ は，いずれも所与の定数であり, それぞ れ, 施設運用に毎時刻必要な管理費用, および施設遊 休中の単位時間あたりの維持費用を表す.

このような状況を想定した上で, 数值計算を行なっ た結果を示そう。.まず, 図-8 は, 初期時刻 $t=0$ にお ける施設運用状態 $\mathrm{A}$ の価值を, 当該時刻での施設需 要 $P(0)=P_{0}$ の関数としてプロットしたものである. 図-8において, 太い実線 $V_{\mathrm{A}}$ は施設運用アクティビ ティの価值を表し, 細い実線 $V_{\mathrm{A}, \mathrm{S}}^{*} \equiv V_{\mathrm{S}}-C_{\mathrm{A}, \mathrm{S}}$ および 点線 $V_{\mathrm{A}, \mathrm{Q}}^{*} \equiv V_{\mathrm{Q}}-C_{\mathrm{A}, \mathrm{Q}}$ は，それぞれ，施設遊休状態お よび更地状態へ切り換えたときの純価值 (i.e. 変更先の 価值から切り換え費用を引いたもの) を表す。この図 において, 施設運用アクティビティの価值 $V_{\mathrm{A}}$ は, 各

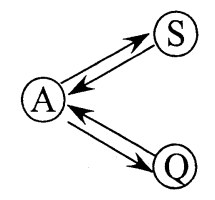

図 7 施設運用・施設遊休・史地のオブション・グラフ

\footnotetext{
*5これは, $P(t)$ が幾何 Brown 連動に従うことを意味している
} 


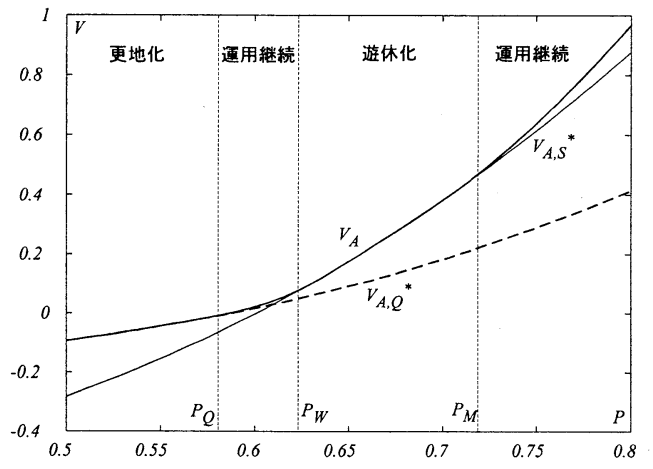

図 8 初期施設需要 $P_{0}$ と施設運用アクティビティ $\mathrm{A}$ の価値

変更先の純価值の包絡線と同じかそれよりも上側を通 る曲線として表される. そして, $V_{\mathrm{A}}$ が $V_{\mathrm{A}, \mathrm{S}}^{*}$ と一致し ている範囲 $\left[P_{\mathrm{W}}, P_{\mathrm{M}}\right]$ では施設遊休化が， $V_{\mathrm{A}}$ が $V_{\mathrm{A}, \mathrm{Q}}^{*}$ に 一致している範囲 $\left[0, P_{\mathrm{Q}}\right]$ では施設の解体 (更地状態へ の変更) が行われることを意味している．また，これ らの境界において, 各アクティビティの価值が smooth pasting 条件および value matching 条件 ${ }^{19)}$ を満たして いることが判る.

ここで, 図-8 の範囲 $\left[P_{\mathrm{Q}}, P_{\mathrm{W}}\right]$ においては, 意思決定 を遅延することのオプション価值 $V_{\mathrm{A}}$ が，アクティビ ティ変更により得られる純価值 $V_{\mathrm{A}, \mathrm{S}}^{*}, V_{\mathrm{A}, \mathrm{Q}}^{*}$ よりも大き い. 寸なわち， $P<E$ ゆえ負の利潤が発生するにも関 わらず，施設の運用が継続される．このことは，事業 主体が， $\left[P_{\mathrm{Q}}, P_{\mathrm{W}}\right]$ において以下の行動をとることを意 味している：たとえ一時的に利潤が負となっても，今 後の需要の変化に備えて当該施設の遊休化および解体 のいずれが有利となるかが判明するまで待つことを選 ぶ.このような行動は，無限満期モデルを用いた従来 型の分析では導かれない.

次に, 図-9 に, 運用アクティビティ A が選択されて いる場合の最適なアクティビティ選択ルールを示す. この図は横軸に時刻 $t$ を, 縦軸に施設需要 $P$ を取り, 任意の時刻と施設需要の組み合わせ $(t, P) \in[0, T] \times \mathcal{R}$ について, 3 つの戦略一 $\mathrm{A} \rightarrow \mathrm{A}$ (現在のアクティビティ を継続), $\mathrm{A} \rightarrow \mathrm{S}$ (施設を遊休化) および $\mathrm{A} \rightarrow \mathrm{Q}$ (更地一 変更)一いずれが最適となるかを示している．例えば， 点@から点@一と施設需要が変化した場合の最適戦略 は以下のように導出される：まず，点(での最適推移 戦略は $\mathrm{A} \rightarrow \mathrm{A}$ であるため, 施設の運用が継続される. そして, 施設需要が点(aまで落ち込み, 最適推移戦略 が $\mathrm{A} \rightarrow \mathrm{S}$ に切り替わると同時に施設は遊休化される. 一方, 施設需要が点@から点(bへの過程を辿った場合, 需要がゆりに到達した時点で施設は解体され, 更地へと

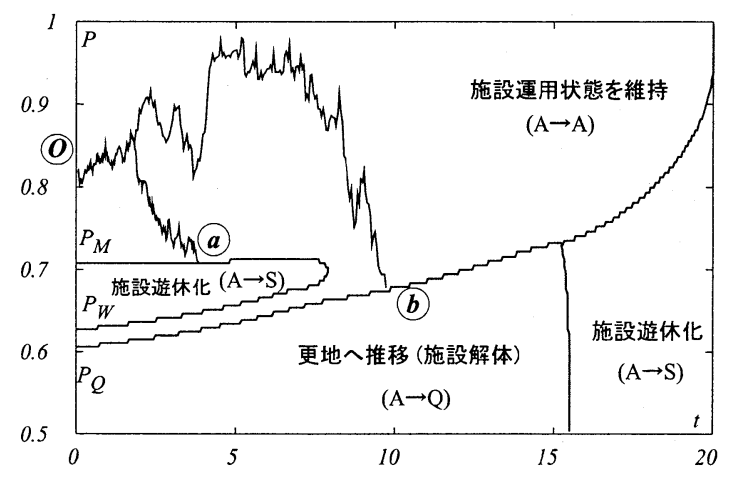

図 9 施設運用アクティビティ $\mathrm{A}$ での最適戦略

変更される.

\section{(7) 本手法の活用例}

筆者らの提案した一般化相補性問題アプローチは, 本稿で示したもの以外にも, 施設管理, 都市計画, 交 通計画などの様々な分野に適用できる．第 1 に，施設 管理の分野へ適用寸る場合の対象として，例えば，小 林らが提唱しているような, ファイナンス工学的アプ ローチを用いた施設の維持・補修問題やライフ・サイ クル・コスト管理問題 $78,79,80,81)$ が挙げられる. これ らの問題は, 施設の劣化の度合いを状態変数とし, 各 瞬間におけるフィードバック的な意思決定を，「微小時 間 $\Delta$ だけ補修を行なわない」と「補修を行なう」との択 一的選択に帰着させることで, その最適性条件を GCP として記述できる.さらに，本文では述べなかったが， 筆者らの提案手法は，(理論的には) 任意の数の状態変 数を取り扱えるため, 個別の劣化特性を持つ複数の施 設の補修問題などへ適用することもできるだろう.

第 2 に, 都市計画分野への適用例の一つとして，土 地の用途規制が不動産価格に与える影響分析が考えら れる.(6) 節で示したように, 不動産は, 経済環境に応 じて，フィードバック的に運用形態を選択でき，その 選択に柔軟性と不可逆性が存在するオプション・グラ フと見なせる．そして，規制による用途の限定は，こ れらの不動産のオプション構造を変化させ, しばしば, 不動産価格の下落を伴う。そのため, 地権者間の合意 を適切に得るには、こうした不動産価格への影響を定 量的かつ詳細に分析する必要がある.このような研究 課題にも，筆者らの提案手法は適用可能である.

最後に, GCP アプローチを交通計画分野へ応用す る場合の対象例の一つとして, 高速道路ランプ流入制 御問題 ${ }^{82,83)}$ が挙げられる. 例えば, 高速道路と一般 道路からなるネットワークを考え, ネットワーク全体 への交通需要が，一日の内でピークを持って確率的に 
変動するとする.ここで, 交通需要に応じてフィード バック的に高速道路への流入量を制御するネットワー ク効率性最大化問題を考える. この問題の最適性条件 もまた GCP として記述できる ${ }^{82,83)}$ ため，その効率的 数值解法の開発などにも，筆者らの研究成果は応用可 能である。

\section{5 おわりに}

本稿では，IP が直面するリスクの計量・管理問題に 対するファイナンス工学的アプローチの適用可能性を 示した. そのために, 従来の (金融・リアル)オプショ ン理論の特徴と限界を俯瞰した，そして，IP 固有の 重要な特徴—“不完備市場りスク”および“連鎖的な意 思決定構造”一を明示的に考慮した枠組へとオプショ ン理論を一般化した筆者らの研究 $20,21,23,22,68)$ を紹介 した.

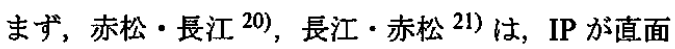
する不完備市場リスクを明示的に考虑した上で，その 動学的財務的価格を行なった. 前者は, オプション評 価理論の基礎となる無裁定条件とミクロ経済学の基礎 となる効用最大化理論を結び付け, 不完備市場リスク の価格を推定するための最小限の仮定を追加したモデ ルを定式化している. 後者は, この枠組を, 権利行使 のタイミング選択も可能なオプションへと拡張し，IP の買手と売手の非対称な行動を明示的に考慮したプロ ジェクト評価手法を開発している.

次に, 赤松・長江 ${ }^{23)}$ おょよび長江・赤松 ${ }^{22)}$ では, IPに 対する意思決定の不可逆性, 柔軟性および連鎖性を考 慮したプロジェクト評価および意思決定を行なった。 この内, 赤松・長江 ${ }^{23)}$ では, 従来, 個々の問題ごとに 個別の分析手法が乱立していたリアル・オプション問 題の数学的構造に着目し, 異なる問題を首尾一貫して 評価する手法を開発している.ここで提案された枠組 は，長江・赤松 22) において一般化され，これまでのア プローチでは取り扱えなかった“オプション・グラブ” 問題を見通し良く記述・分析することを可能にした.

上述の研究は, いずれも, 現実の IP の定量的な財 務的評価および意思決定に要求される 3 つの自然な要 件 : (1)連続時間-連続状態の枠組の下で現実的な仮定を おいたそデルを扱える；(2)異なるプロジェクトに対し ても首尾一貫した記述・分析が行なえる胃通しの良い 枠組である; (3)具体的に必要な計算が効率的に行なえ る;満たす手法の構築を目指したものである.

筆者らの手法を現実のプロジェクトに適用するに は, 状態変数 (e.g., 交通量, 取扱貨物量, 財価格, 為
替)が従う確率過程を，個々の問題ごとに特定化する必 要がある.そして，そのためには，状態変数に関する 動学的データの収集および分析が必要不可欠である. こうしたデータは，実は，従来から観測は可能であっ たように思われる. また，近年の情報技術の進展によ り、これまで不可能と思われていた高頻度・高精度な データの観測・収集 (e.g., 無線 IC タグを利用した施設 の劣化状態の観測や，移動体通信機器を用いた交通利 用者の動態把握など) も可能となりつつある. しかし, IP が直面するリスクの計量・管理といった視点では, こうしたデータの収集・整理が網羅的・体系的ではな く，その方法論やプロトコルも確立しているとは言い 難い. そして，その要因の一つとして，費用便益分析 などの従来理論の多くが静学的枠組をベースに構築さ れており, “動学的データを収集しても使い道がない” 状況であったことが挙げられよう，筆者らの研究は, 動学的データの観測・分析を前提とした，見通しの良 い理論的枠組を提案するものであり，こうした状況の 改善を助けるものと考えらえる.

このような “理論モデルの構筑” と “実証的検証” と いう研究の両輪と, それを結びつける“データの観測・ 蓄積・分析技術” の有機的な連係は，高度な理論体系の 発展を支える重要なファクターである. それが顕著な 分野の一つが, 本稿がベースとするファイナンス理論 である.この分野では，ある優れた理論モデルが構筑 されると, その実証的妥当性に関して緻密な検証が行 なわれる. そして，そのモデルではどうしても説明で きない “puzzle”や“paradox”が発見されることで，さ らなる理論の一般化・高度化が試みられる。こうした “理論体系の life cycle” と, そこに従事する研究者の真 摰な切硡㻟磨の姿勢によって, これらの分野では, 現 在も，日進月歩の理論・技術進展が実現されている.

このような理論・観測・実証の有機的連保は, 従来, 土木計画分野においても重視されてきており, 費用便 益理論や交通ネットワーク均衡理論などの発展を支え てきた. 本稿は, こうした有機的連係を動学的枠組へ と桩張する試みの一つである. そして, この有機的連 係が土木計画分野における “dynamic”な理論進展をも たらす際に，筆者らの研究が貢献できれば幸いである.

\section{謝辞}

本稿を執筆するにあたり, 多くの方々との議論の中 で, 貴重な意見・助言を戴いた. 特に, 東北大学大学 院 森杉壽芳教授, 稲村肇教授, 佐々木公明教授, 京都 大学大学院小林潔司教授, 京都大学防災研究所多々納 
裕一教授, 神戸大学大学院 朝倉康夫教授, 東京大学羽 藤英二助教授には, 有益な示唆を多く戴いた. ここに 記して感謝する.

\section{付録 ファイナンス(資産価格・オプシ ヨン評価) 理論に関する教科書・ 専門書}

本稿では, 筆者らの研究 ${ }^{20,21,23,22,68)}$ がベースとす る (金融・リアル)オプション理論や，それを含む資産 価格評価理論については，あえて解説を省いた，その 理由は，これらの理論の体系的内容に関しては，様々 なレベル・観点で書かれた良質なテキストが無数に存 在するため, 限られた紙面上で無理に説明するよりも, 読者自身でこうしたテキストに目を通していただく 方が効率的だからである，以下では，そのために特に 有益と思われるテキストを, トピックごとに紹介して おく.

A.1 リアル・オプション理論

- Dixit, A.: The Art of Smooth Pasting, Vol. 55 of Fundamentals of Pure and Applied Economics, Harwood Academic Publishers, Chur, Switzerland, 1993.

- Dixit, A. K. and Pindyck, R. S.: Investment Under Uncertainty, Princeton University Press, Princeton, 1994.

- Schwartz, E. S. and Trigeorgis, L. eds.: Real Options and Investment Under Uncertainty: Classical Readings and Recent Contributions, MIT Press, 2001.

- Trigeorgis, L.: Real Options: Managerial Flexibility and Strategy in Resource Allocation, MIT Press, Cambridge, 1996.

- Miranda, M. J. and Fackler, P. L.: Applied Computational Economics and Finance, MIT press, 2004.

- Grenadier, S.: Game Choices: the Intersection of Real Options and Game Theory, Risk books, 2000.

- Brennan, M. J. and Trigeorgis, L.: Project Flexibility, Agency and Competition: New Developments in the Theory and Applications of Real Options, Oxford University Press, 2000.

\section{A.2 金融オプション理論 (入門〜中級)}

- Cox, J. C. and Rubinstein, M.: Option Markets, Princeton-Hall, Englewood Cliffs, NJ, 1985.

- Hull, J.: Options, Futures and Other Derivative Securities, Princeton-Hall, Englewood Cliffs, NJ, 1989.

- Jarrow, R. A.: Modeling Fixed Income Securities and Interest Rate Options, McGraw-Hill, 1996.

- Grandville, O.: Bond Pricing and Portfolio Analysis: Protecting Investors in the Long Run, MIT Press, 2001.

- Wilmott, P.: Paul Wilmott on Quantitative Finance, John Wiley \& Sons, 2000.

- Neftci, S. N.: An Introduction to the Mathematics of
Financial Derivatives, Academic press, 1996.

- Neftci, S. N.: Principles of Financial Engineering, Academic press, 2004.

- Baxter, M. and Rennie, A.: Financial Calculus: An Introduction to Derivative Pricing, Cambridge University Press, 1996.

- Nielsen, L. T.: Pricing and Hedging of Derivative Securities, Oxford University Press, 1999.

- Joshi, M. S.: The Concepts and Practice of Mathematical Finance, Cambridge University Press, 2004.

- Bhansali, V.: Pricing and Managing Exotic and Hybrid Options, McGraw-Hill, 1998.

- Schönbucher, P. J.: Credit Derivatives Pricing Models: Model, Pricing and Implementation, John Wiley \& Sons, 2003.

- Björk, T.: Arbitrage Theory in Continuous Time, Oxford University Press, 1998.

A.3 数理ファイナンス (上級)

- Föllmer, H. and Schied, A.: Stochastic Finance: an Introduction in Discrete Time, Walter de Gruyter, 2002.

- Shiryaev, A. N.: Essentials of Stochastic Finance : Facts, Models, Theory, World Scientific Publishing Company, 1999.

- Dempster, M. A. H. and Pliska, S. R. eds.: Mathematics of Derivative Securities, Cambridge University Press, 1997.

- Davis, M. H., Duffie, D., Fleming, W. H. and Shreve, S. E. eds.: Mathematical Finance, SpringerVerlag, 1995.

- Karatzas, I. and Shreve, S. E.: Methods of Mathematical Finance, Springer-Verlag, New York, 1998.

A.4 資産価格理論を中心とするファイナンス理論全 般

(a) 入門-中級

- Luenberger, D. G.: Investment Science, Oxford University Press, NY, 1998.

- Ho, T. S. Y., Lee, S. B. and Yi, S.-B.: The Oxford Guide to Financial Modeling: Applications for Capital Markets, Corporate Finance, Risk Management and Financial Institutions, Oxford University Press, 2004.

- Ross, S. A., Westerfield, R. W. and Jaffe, J.: Corporate Finance, McGraw-Hill//rwin, 1998.

(b) ハンドブック

- Constantinides, G. M., Harris, M. and Stulz, R. M. eds.: Financial Markets and Asset Pricing, Vol. 1B of Handbook of the Economics of Finance, NorthHolland, 2003.

- Campbell, J. Y., Lo, A. W. and MacKinlay, A. C.: The Econometrics of Financial Markets, Princeton University Press, 1997.

- Jarrow, R. A., Maksimovic, V. and Ziemba, W. T. eds.: Finance, Vol. 9 of Handbooks in Operations Research 
and Management Science, North-Holland, 1995.

A.5 動的ポートフォリオ理論〜金融資産価格理論

(a) 離散時間 (入門〜中級)

- Pliska, S. R.: Introduction to Mathematical Finance, Blackwell, 1997.

- Cerny, A.: Mathematical Techniques in Finance: Tools for Incomplete Markets, Princeton University Press, 2003.

- Huang, C.-F. and Litzenberger, R. H.: Foundations for Financial Economics, North-Holland, 1988.

(b) 連続時間 (上級)

- Korn, R. and Korn, E.: Option Pricing and Portfolio Optimization: Modern Methods of Financial Mathematics, American Mathematical Society, 2001.

- Merton, R. C.: Continuous Time Finance, Blackwell, 1990.

- Ingersoll, J. E. Jr.: Theory of Financial Decision Making, Rowman \& Littlefield, 1987.

- Duffie, D.: Dynamic Asset Pricing Theory, Princeton University Press, Princeton, 1992.

- Cochrane, J. H.: Asset Pricing, Princeton University Press, Princeton, 2001.

\section{A.6 資産価格理論の一般均衡論的基礎}

- Danthine, J.-P. and Donaldson, J. B.: Intermediate Financial Theory, Academic Press, 2001.

- Eichberger, J. and Harper, I. R.: Financial Economics, Oxford University Press, 1997.

- Milne, F.: Finance Theory and Asset Pricing, Oxford University Press, 2003.

- Gollier, C.: The Economics of Risk and Time, MIT Press, 2001

- Bossaerts, P.: The Paradox of Asset Pricing, Princeton University Press, 2002.

- Ross, S. A.: Neoclassical Finance, Princeton University Press, 2005.

- LeRoy, S. F. and Werner, J.: Principles of Financial Eonomics, Cambridge University Press, Cambridge, UK, 2001.

- Magill, M. and Quinzii, M.: Theory of Incomplete Markets, MIT Press, 1996.

- Hens, T. and Pilgrim, B.: General Equilibrium Foundations of Finance: Structure of Incomplete Markets Models, Kluwer Academic Publishers, 2002.

A.7 金融リスク管理・その他

- Szegö, G. ed.: Risk Measures for the 21st Century, John Wiley \& Sons, 2004.

- Cherubini, U., Luciano, E. and Vecchiato, W.: Copula Methods in Finance, John Wiley \& Sons, 2004.

参考文献

1) Black, F. and Sholes, M.: The pricing of options and corporate liabilities, Journal of Political Economy,
Vol. 81, pp. 637-659, 1973.

2) Merton, R. C.: The theory of rational option pricing, Bell Journal of Economics and Management Science, Vol. 4, pp. 141-183, 1973.

3) Harrison, J. M. and Kreps, D.: Martingale and arbitrage in multiperiod securities markets, Journal of Economic Theory, Vol. 20, pp. 381-408, 1979.

4) Harrison, J. M. and Pliska, S. R.: Martingales and stochastic integrals in the theory of continuous trading, Stochastic Process and Their Applications, Vol. 11, pp. 215-260, 1981.

5) Heath, D., Jarrow, R. A. and Morton, A.: Bond pricing and the term structure of interest rates: A discrete time approximation, Journal of Financial and Quantitative Analysis, Vol. 25, No. 4, pp. 419-440, 1990.

6) Heath, D., Jarrow, R. A. and Morton, A.: Bond pricing and the term structure of interest rates: $A$ new methodology for contingent claims valuation, Econometrica, Vol. 60, pp. 77-106, 1992.

7) Sharpe, W.: Capital asset prices; a theory of market equilibrium under conditions of risk, Journal of Finance, Vol. 19, pp. 425-442, 1964.

8) Lintner, J.: The valuation of risky assets and the selection of risky investments in stock portfolios and capital budgets, Review of Economics and Statistics, Vol. 47, pp. 13-37, 1965.

9) Mossin, J.: Equilibrium in a capital asset market, Econometrica, Vol. 35, pp. 768-783, 1966.

10) Merton, R. C.: An intertemporal capital asset pricing model, Econometrica, Vol. 41, pp. 867-887, 1973.

11) Breeden, D. T.: An intertemporal asset pricing model with stochastic consumption and investment opportunities, Journal of Financial Economics, Vol. 7, pp. 265-296, 1979.

12) Mehra, R. and Prescott, E.: The equity premium puzzle, Journal of Monetary Economics, Vol. 15, pp. 145-161, 1985.

13) Weil, P.: The equity premium puzzle and the riskfree rate puzzle, Journal of Monetary Economics, Vol. 24, No. 2, pp. 401-421, 1989.

14) Brennan, M. J. and Schwartz, E. S.: Evaluating natural resource investments, Journal of Business, Vol. 58, No. 2, pp. 135-157, 1985. 
15) McDonald, R. and Siegel, D.: Investment and the valuation of firms when there is an option to shut down, International Economic Review, Vol. 26, No. 2, pp. 331-349, 1985.

16) McDonald, R. and Siegel, D.: The value of waiting to invest, Quarterly Journal of Economics, Vol. 101, No. 4, pp. 707-727, 1986.

17) Henry, C.: Investment decisions under uncertainty: The irreversibility effect, American Economic Review, Vol. 64, pp. 1006-1012, 1974.

18) Arrow, K. J. and Fisher, A. C.: Environmental preservation, uncertainty, and irreversibility, Quarterly Journal of Economics, Vol. 88, pp. 312-319, 1974.

19) Dixit, A. K. and Pindyck, R. S.: Investment under Uncertainty, Princeton University Press, Princeton, 1994.

20) 赤松隆,長江剛志 : 経済リスクを考慮した社会基盤 投資プロジェクトの動学的財務評価, 土木学会論 文集, No. 751/IV-62, pp. 39-54, 2004.

21）長江剛志, 赤松隆: 不完備市場リスク要因を考慮し たリアル・オプション評価, 応用地域学研究, Vol. 8, No. 2, pp. 81-93, 2003.

22）長江剛志, 赤松隆 : 連鎖的な意思決定構造を持つプ ロジェクトの動学的評価法 : オプション・グラフ・ モデルとその解法, 土木学会論文集, No. 772/IV-65, pp. 185-202, 2004.

23）赤松隆,長江剛志 : 不確実性下での社会基盤投資 ・ 運用問題に対する変分不等式アプローチ, 土木学 会論文集, No. 765/IV-64, pp. 155-171, 2004.

24) Hansen, L. P. and Jagannathan, R.: Implications of security market data for models of dynamic economies, Journal of Political Economy, Vol. 99, pp. 225-262, 1991.

25) Hansen, L. P. and Jagannathan, R.: Assessing specification errors in stochastic discount factor models, The Journal of Finance, Vol. 52, No. 2, 1997.

26) Knight, F. H.: Risk, Uncertainty and Profit, Houghton, Mifflin, Boston, 1921.

27) Ellsberg, D.: Risk, ambiguity, and the Savage axioms, Quarterly Journal of Economics, Vol. 75, pp. 643-669, 1961.

28) von Neumann, J. and Morgenstern, O.: Theory of Games and Economic Behavior, Princeton University Press, 1947.
29) Savage, L. J.: The Foundations of Statistics, John Wiley, New York, 1954.

30) Gilboa, I.: Expected utility with purely subjective non-additive probabilities, Journal of Mathematical Economics, Vol. 16, pp. 65-88, 1987.

31) Schmeidler, D.: Subjective probability and expected utility without additivity, Econometrica, Vol. 57, pp. 571-587, 1989.

32) Gilboa, I. and Schmeidler, D.: Maxmin expected utility with non-unique prior, Journal of Mathematical Economics, Vol. 18, pp. 141-153, 1989.

33）尾崎裕之：ナイト流不確実性と均衡価格の不決定 性, 西村和雄, 福田慎一（編）, 非線形均衡動学, 第 11 章, 東京大学出版会, 2004.

34) Epstein, L. G. and Wang, T.: Intertemporal asset pricing under Knightian uncertainty, Econometrica, Vol. 62, No. 3, pp. 283-322, 1994.

35) Chen, Z. and Epstein, L. G.: Ambiguity, risk, and asset returns in continuous time, Econometrica, Vol. 70, No. 4, pp. 1403-1443, 2002.

36) Hansen, L. P. and Sargent, T. J.: Discounted linear exponential quadratic Gaussian control, IEEE Transactions on Automatic Control, Vol. 40, pp. 968-971, 1995.

37) Anderson, E. W., Hansen, L. P. and Sargent, T. J.: A quartet of semigroups for model specification, robustness, prices of risk, and model detection, Journal of the European Economic Association, Vol. 1, No. 1, pp. 68-123, 2003.

38) Hansen, L. P. and Sargent, T. J.: Robust control and model uncertainty, American Economic Review, Vol. 91, pp. 60-66, 2001.

39) Epstein, L. G. and Miao, J.: A two-person dynamic equilibrium under ambiguity, Journal of Economic Dynamics E Control, Vol. 27, pp. 1253-1288, 2003.

40) Maenhout, P. J.: Robust portfolio rules and asset pricing, The Review of Financial Studies, Vol. 17, No. 4, pp. 951-983, 2004.

41) Uppal, R. and Wang, T.: Model misspecification and underdiversification, The Journal of Finance, Vol. 58, No. 6, pp. 2465-2486, 2003.

42) Liu, J., Pan, J. and Wang, T.: An equilibrium model of rare-event premia and its implication for option smirks, The Review of Financial Studies, Vol. 18, No. 1, pp. 131-164, 2005. 
43) Duffie, D. and Pang, J.: An overview of value at risk, The Journal of Derivatives, Vol. 4, pp. 7-49, 1997.

44) Artzner, P., Delbaen, F., Eber, J.-M. and Heath, D.: Thinking coherently, Risk, Vol. 10, pp. 68-71, 1997.

45) Artzner, P., Delbaen, F., Eber, J.-M. and Heath, D.: Coherent measures of risk, Mathematical Finance, Vol. 9, No. 3, pp. 203-228, 1999.

46) Delbaen, F.: Coherent measures of risk on general probability spaces, in Sandmann, K. and Schönbucher, eds., Advances in Finance and Stochastics, pp. 1-37, Springer-Verlag, New York, 2002.

47) Frittelli, M. and Rosazza Gianin, E.: Dynamic convex risk measures, in Szegö, G. ed., Risk Measures for the 21st Century, chapter 12, pp. 227-248, John Wiley \& Sons, 2004.

48) Rockafellar, R. T. and Uryasev, S.: Conditional value-at-risk for general loss distributions, Journal of Banking E Finance, Vol. 26, No. 7, pp. 14431471, 2002.

49) Föllmer, H. and Schied, A.: Robust preferences and convex measures of risk, in Sandmann, $\mathrm{K}$. and Schönbucher, eds., Advances in Finance and Stochastics, pp. 39-56, Springer-Verlag, New York, 2002.

50) Dow, J. and Werlang, S. R. d. C.: Nash equilibrium under Knightian uncertainty: Breaking down backwad induction, The Journal of Economic Theory, Vol. 64, pp. 305-324, 1994.

51) Marinacci, M.: Ambiguous games, Games and Economic Behavior, Vol. 31, pp. 191-219, 2000.

52) Haller, H.: Non-additive beliefs in solvable games, Theory and Decision, Vol. 49, pp. 313-338, 2000.

53) Klibanof, P.: Uncertainty, decision, and normal form games, working paper, Northwestern University, 1996.

54) Lo, K. C.: Equilibrium in beliefs under uncertainty, The Journal of Economic Theory, Vol. 71, pp. 443484, 1996.

55) Eichberger, J. and Kelsey, D.: Non-additive beliefs and strategic equilibria, Games and Economic Behavior, Vol. 30, pp. 183-215, 2000.

56) 大西正光, 坂東弘, 小林潔司: Pfi 事業におけるリ スク分担ルール, 都市計画学会論文集, No. $38, \mathrm{pp}$. 289-2, 2003.
57) 大西正光, 坂東弘, 小林潔司 : Pfi 事業のための事業 再生手続き, 建設マネジメント研究論文集, Vol. 11, pp. 181-192, 2004.

58) Geske, R.: The valuation of compound options, Journal of Financial Economics, Vol. 7, No. 1, pp. 1235-1256, 1979.

59) Grenadier, S. and Weiss, A.: Investment in technological innovations: An option pricing approach, Journal of Financial Economics, Vol. 44, pp. $397-$ 416, 1997.

60) Farzin, Y. H., Huisman, K. J. M. and Kort, P. M.: Optimal timing of technology adoption, Journal of Economic Dynamics $\mathcal{E}$ Control, Vol. 22, pp. 779799, 1998.

61) Doraszelski, U.: The net present value method versus the option value of waiting: A note on Farzin, Huisman and Kort(1998), Journal of Economic Dynamics $\mathcal{E}$ Control, Vol. 25, pp. 1109-1115, 2001.

62) Dixit, A. K. and Pindyck, R. S.: Investment under Uncertainty, chapter 10, Princeton University Press, 1994.

63) Margrabe, W.: The value of an option to exchange one asset for another, The Journal of Finance, Vol. 33, No. 1, pp. 177-186, 1978.

64) Stulz, R. M.: Options on the minimum or the maximum of two risky assets, Journal of Financial Economics, Vol. 10, No. 2, pp. 161-185, 1982.

65) Dixit, A. K.: Investment and hysteresis, Journal of Economic Perspective, Vol. 6, pp. 107-132, 1992.

66) Dixit, A. K. and Pindyck, R. S.: Investment under Uncertainty, chapter 7, Princeton University Press, 1994.

67) Kulatilaka, N.: The value of flexibility: A general model of real options, in Trigeorgis, L. ed., Real Options in Capital Investment, Praeger, 1995.

68) Nagae, T. and Akamatsu, T.: A generalized complementarity approach to solving real option problems, submitted to Journal of Economic Dynamics $\mathcal{E}$ Control.

69) Cottle, R. W. and Dantzig, G. B.: A generalization of the linear complementarity problem, Journal of Combinatorial Theory, Vol. 8, pp. 79-90, 1970.

70) Ferris, M. C. and Pang, J.-S.: Engineering and economic applications of complementarity problems, SIAM Review, Vol. 39, No. 4, pp. 669-713, 1997. 
71) Jiang, H., Fukushima, M., Qi, L. and Sun, D.: A trust region method for solving generalized complementarity problems, SIAM Journal on Optimization, Vol. 8, No. 1, pp. 140-157, 1998.

72) Peng, J.-M.: A smoothing function and its applications, in Fukushima, M. and Qi, L. eds., Reformulation: Nonsmooth, Piecewise Smooth, Semismooth and Smoothing Methods, pp. 293-316, Kluwer Academic Publishers, 1999.

73) Qi, H.-D. and Liao, L.-Z.: A smoothing Newton method for extended vertical linear complementarity problem, SIAM Journal on Matrix Analysis and Applications, Vol. 21, No. 1, pp. 45-66, 1999.

74) Qi, H.-D., Liao, L.-Z. and Lin, Z.-H.: Regularized smoothing approximations to vertical nonlinear complementarity problems, Journal of Mathematical Analysis and Applications, Vol. 230, pp. 261276, 1999.

75) Peng, J.-M. and Lin, Z.: A non-interior continuation method for generalized linear complementarity problem, Mathematical Programming, Vol. 86, pp. 533-563, 1999.

76) Qi, H.-D. and Liao, L.-Z.: A smoothing Newton method for general nonlinear complementarity problems, Computational Optimization and Applications, Vol. 17, pp. 231-253, 2000.

77) Chen, C. and Mangasarian, O. L.: A class of smoothing functions for nonlinear and mixed complementarity problems, Computational Optimization and Applications, Vol. 5, pp. 97-138, 1996.

78）栗野盛光, 小林潔司, 渡辺晴彦: 不確実性下におけ る最適補修ルール, 土木学会論文集, No. 667/IV-50, pp. 1-14, 2001.

79) 慈道充, 小林潔司 : 不確実性下における最適点検 修繥ルール, 土木学会論文集, No. 744/IV-61, pp. 39-50, 2003.

80) 織田澤利守, 石原克治, 小林潔司, 近藤佳史 : 経済 的寿命を考慮した最適修縜政策, 土木学会論文集, No. 772/IV-65, pp. 169-184, 2004.

81) 小林潔司, 上田孝行：インフラストラクチャ・マネ ジメント研究の課題と展望, 土木学会論文集, No. 744/IV-61, pp. 15-27, 2003.

82) Nagae, T. and Akamatsu, T.: Dynamic revenue management of a toll road project under transportation demand uncertainty, Networks and Spatial Eco- nomics, forthcoming.

83）山崎周一, 赤松隆 : 不確実性に対するリスク回避度 を考慮した動的システム最適配分, 土木計画学研 究・講演集, Vol. 32, CD-ROM, 2005.

(2006年 8 月 20 日) 